\title{
Physiological responses and the uptake of cadmium and zinc by the amphipod crustacean Orchestia gammarellus
}

\author{
Philip S. Rainbow*, Michael K. H. Kwan** \\ School of Biological Sciences, Queen Mary and Westiield College, University of London, Mile End Road, \\ London E1 4NS, United Kingdom
}

\begin{abstract}
The rates of uptake of cadmium and zinc by the amphipod crustacean Orchestia gammarellus (Pallas) increase with decrease in salinity from 36.5 to $25 \% \mathrm{NaCl}$, as expected from physicochemical changes in the availabilities of free metal ions. Between 15 and $25 \% \mathrm{NaCl}$ cadmium and zinc uptake rates plateau, and the cadmium uptake rate falls at $12 \% \mathrm{NaCl}$. This pattern of change of uptake rate with salinity change is not dependent on trace metal exposure concentrations, and cannot be explained by uptake via any enzyme-driven uptake route. It is concluded that at low salinity the amphipods effect one or more physiological responses that offset any increases in cadmium and zinc uptake rates expected from physico-chemical increases in the availabilities of free metal ions at low salinity. Such physiological responses are induced by changes in total osmolality, as opposed to inorganic salinity, and are not maintained on transfer from low to high osmolality. The physiological response is not explicable only in terms of change of the uptake rate of calcium, nor only in terms of change in apparent water permeability which may play a role at extremely low salinities. In low salinity the amphipods do excrete newly accumulated cadmium and zinc but this excretion does not explain the lack of increase in net uptake of cadmium and zinc at low salinities. The identification of the physiological response of $O$. gammarellus reducing trace metal uptake at low salinity remains enigmatic, and may turn out to be combination of several effects.
\end{abstract}

KEY WORDS: Trace metal - Heavy metal - Cadmium - Uptake - Salinity - Osmolality Water permeability $\cdot$ Calcium pump Orchestia Amphipod crustacean

\section{INTRODUCTION}

Marine and estuarine crustaceans, like all aquatic organisms, are bathed in a solution of trace metals, including cadmium and zinc, at dissolved concentrations which decrease from estuaries, through coastal seas, to the surface waters of open oceans (Bruland 1983). Trace metals are taken up and accumulated by these crustaceans to high body concentrations (Rainbow 1987, 1988, 1993). Uptake takes place from food sources in the alimentary tract but also from solution across permeable surfaces such as gills.

\footnotetext{
•E-mail: p.rainbow@qmw.ac.uk

- Present address: Department of Zoology, Natural History Museum, Cromwell Road, London SW7 5BD, United Kingdom
}

Possible mechanisms for the uptake of trace metals from solution have been reviewed by Simkiss \& Taylor (1989), and it is quite probable that more than one uptake route is in operation (Rainbow \& Dallinger 1993, Rainbow 1995), with different routes predominating according to species and ecological specialisation.

One model explaining many of the results of trace metal uptake experiments with crustaceans (e.g. Nugegoda \& Rainbow 1988, 1989a, b, O'Brien et al. 1990 ) is that whereby the free metal ion, released from complexation equilibria in solution, binds onto a carrier protein in the cell membrane and is transferred passively into the epithelial cell and beyond by facilitated diffusion along a series of metal-binding ligands of increasing affinity (Simkiss \& Taylor 1989, Rainbow et al. 1993, Rainbow 1995). Cadmium and zinc in sea- 
water are complexed with inorganic ligands such as chloride (e.g. $\mathrm{CdCl}^{+}, \mathrm{CdCl}_{2}{ }^{0}, \mathrm{CdCl}_{3}{ }^{-}$) (Zirino \& Yamamoto 1972, Mantoura et al. 1978, Rainbow et al. 1993). Any physico-chemical change reducing the hydrophilic complexation of cadmium or zinc in seawater will increase the availability of the free metal ion, and correspondingly increase cadmium or zinc bioavailability according to this model. Thus the uptake rate of cadmium or zinc into an exposed crustacean would rise, dependent only on the physicochemical change in the medium, beyond the physiological control of the crustacean itself. A reduction in salinity necessarily reduces concentrations of chloride and other inorganic ligands and would produce such an effect.

Another route for the uptake of dissolved cadmium involves its incorporation into calcium pumps (Wright 1977b, 1980, Simkiss \& Taylor 1989, Rainbow 1995). Unlike trace metals, major metal ions (e.g. $\mathrm{Na}^{+}, \mathrm{K}^{+}$, $\mathrm{Ca}^{2+}$ ) do not have high affinities for organic ligands (Nieboer \& Richardson 1980) and require active transport pumps for movement against concentration gradients into and/or out of cells. Calcium is taken up, apparently via gated channels, by chloride cells in the gills of estuarine crabs, probably depending on energy generated in a $\mathrm{Na}^{+} / \mathrm{K}^{+}$ATPase system (Böttcher \& Siebers 1993, Towle 1993). The free cadmium ion has a similar ionic radius (109 pm) to that of the calcium ion (114 pm) (typical coordination number $=6$ in each case; see Huheey 1983), and it is inevitable that some cadmium will become 'accidentally' incorporated into the calcium uptake route. The action of the calcium pump is under the physiological control of the crab (Mantel \& Farmer 1983) (or equivalent crustaceans including amphipods), and so the relative importance of this route of cadmium uptake will vary with crustacean species and physiological and ecological conditions. Thus, a newly moulted crustacean may well have an enhanced calcium uptake rate to facilitate calcification of its new cuticle. Similarly zinc may also become incorporated into major ion pumps.

In particular, an estuarine crustacean in reduced salinity will increase its uptake rate of calcium and other major ions. Crustaceans thus exposed to media hypotonic to their body fluids respond to the increased osmotic entry of water by increasing urine production; in most crustaceans the urine is isotonic to the blood and therefore the increased expulsion of water leads to a concomitant loss of major ions (e.g $\mathrm{Ca}^{2+}$ ) in the urine (Mantel \& Farmer 1983). This loss is balanced by active uptake against concentration gradients in the gills. Thus a decrease in. salinity would cause increased uptake of calcium, and therefore of cadmium if this route of cadmium uptake is significant, irrespective of any physico-chemical change in chloride complexation in the medium. Thus cadmium uptake is potentially under physiological control. Incidentally it also follows that physico-chemical changes in the medium that promote the percentage contribution of the free cadmium ion to the unchanged total cadmium concentration would also promote cadmium incorporation into the calcium channel, even in the absence of any change in the calcium concentration.

Thus at least 2 routes for the uptake of dissolved cadmium and zinc are available to crustaceans, passive facilitated diffusion and access via active uptake routes for calcium and other major ions which is likely to be of more significance in a postmoult crustacean calcifying its cuticle or in an estuarine crustacean undertaking osmoregulation. Inevitably, therefore, the 2 routes will vary in their significance according to species and habit. Certainly published evidence typically supports the prediction of either model that decreased salinity promotes cadmium and zinc uptake by crustaceans for example in the amphipods Orchestia gammarellus (Rainbow et al. 1993) and Gammarus pulex (Wright 1980), in the caridean decapods Palaemon elegans and Palaemonetes varians (Nugegoda \& Rainbow 1989a, b), and in the crabs Callinectes sapidus (Hutcheson 1974), Uca pugilator (O'Hara 1973a, b) and Carcinus maenas (Wright 1977a). Interpretations of which uptake route is involved understandably vary. In the case of evidence favouring involvement of the calcium route, Wright (1977b) has shown that calcium concentration has an effect on cadmium uptake by $C$. maenas independent of a salinity effect, and cadmium accumulation by the freshwater amphipod $G$. pulex is at least partially accounted for by uptake via the calcium pump (Wright 1980). On the other hand physico-chemical speciation effects alone predict cadmium and zinc uptake by $O$. gammarellus over the salinity range 36.5 to $25 \%$ (Rainbow et al. 1993). Studies on the uptake rate of zinc by Palaemon elegans using hydrophilic complexing agents and differential changes in salinity and osmolality have shown that the activity of the free metal ion under physico-chemical control in solution predicts metal uptake rates and rules out a significant uptake role for any major ion pump (Nugegoda \& Rainbow 1988, 1989a, b, O'Brien et al. 1990).

A further complication exists however. Both zinc and cadmium uptake rates by Orchestia gammarellus increase with reduction in salinity down to $25 \%$ in correlation with the predicted. concentrations of the free metal ions, but at $15 \%$ the uptake rate of each metal equals that at $25 \%$ (Rainbow et al. 1993). This is unexpected by either model which would predict an increase in trace metal uptake rate with further decrease in salinity as the free metal ion concentrations continue to rise (Rainbow et al. 1993). The graphs of cadmium and zinc uptake against respective free 
metal ion concentration show a plateau (Rainbow et al. 1993), at first sight reminiscent of a saturation effect in an enzyme mediated process (Simkiss pers, comm.). This suggestion bears further investigation although most data sets on the uptake of trace metals by crustaceans are interpretable in terms of passive facilitated diffusion processes (e.g. Bryan 1966, 1968, White \& Rainbow 1984). Indeed Rainbow et al. (1993) interpreted the 2 graphs referred to above in terms of the induction of a physiological response on the part of the euryhaline amphipod to a threshold low salinity.

A number of estuarine crustaceans have a remarkable response to low salinity that might offer further potential for physiological control over trace metal uptake. Certain crustaceans such as Carcinus maenas (Smith 1970) Gammarus duebeni (Lockwood \& Inman 1973, Bolt 1983) and Palaemon longirostris (Campbell \& Jones 1990) show a decrease in apparent water permeability (AWP) in low salinity, probably reflecting real changes in integumental permeability (Mantel \& Farmer 1983, Campbell \& Jones 1990).

Indeed Chan et al. (1992) found apparently anomalous results in the effect of reduced salinity on cadmium and zinc uptake rates in Carcinus maenas. For example, in crabs from a fully marine acclimated (Scottish) population exposed to labelled cadmium at 33, 25 and $15 \%$ salinity, the cadmium uptake rate was highest in 33\%; in Danish crabs from a population living at ca $17 \%$ the cadmium uptake rate was highest at $15 \%$. Chan et al. (1992) proposed that the Scottish crabs were showing a physiological response to low salinity (possibly a change in AWP) counteracting the physicochemical promoter effect of reduced chloride complexation on cadmium uptake rate, whereas the Danish crabs had already effected such a physiological change and cadmium uptake rates followed physicochemical changes only (see also Rainbow 1995). The zinc uptake results were interpreted similarly (Chan et al. 1992).

This study sets out to examine further the interaction of physiology and physico-chemistry on the rates of uptake of cadmium and zinc by the amphipod crustacean Orchestia gammarellus. It addresses the possible saturation of trace metal uptake expected if an enzyme system drives trace metal uptake, and measures changes in AWP and calcium uptake rate in an attempt to correlate them with observed changes in cadmium and zinc uptake rates under different physico-chemical conditions. Much of the methodology is that described by Rainbow et al. (1993). Weeks \& Rainbow (1991) have shown that all zinc taken up from solution at $33 \%$ is accumulated by Orchestia gammarellus without excretion, and all crustaceans appear to be net accumulators of dissolved cadmium (Rainbow $1987,1988,1993)$. The short-term rate of accumulation of labelled cadmium or zinc is therefore used as a measure of the absolute rate of uptake of either metal into the amphipod.

\section{MATERIALS AND METHODS}

Orchestia gammarellus (Pallas) were collected from the strandline on Great Cumbrae Island $\left(55^{\circ} 44^{\prime} \mathrm{N}\right.$; $4^{\circ} 54^{\prime}$ W), Firth of Clyde, Scotland, UK, between May 1992 and May 1994. In the laboratory they were maintained in $20 \mathrm{l}$ acid-washed covered plastic tanks with gravel wetted with seawater at $33 \%$, and fed on castup Laminaria digitata from Great Cumbrae Island $\left(10^{\circ} \mathrm{C} ; 12 \mathrm{~h}\right.$ light:dark).

Experiments were carried out at $10^{\circ} \mathrm{C}$ in a fully aerated artificial medium of $\mathrm{NaCl}$ (Analar grade, $\mathrm{BDH}$, Poole, UK) in double distilled water with a $\mathrm{pH}$ of 6.8 , adjusted as necessary with $0.05 \mathrm{M} \mathrm{NaOH}$ (Analar grade, $\mathrm{BDH}$ ) or $\mathrm{HCl}$ (Aristar grade, $\mathrm{BDH}$ ). This medium could be made up to different salinities $(\% \mathrm{NaCl})$ and the speciation of any added cadmium or zinc modelled by modified versions of SPECIES (L. D. Pettit) and SEAWATER (P. O'Brien) computer programs (see Rainbow et al. 1993), based on equilibrium data in the literature (Turner et al. 1981).

All experimental equipment including tanks and amphipod holders were presoaked in 2 changes of experimental media to offset adsorption effects (Rainbow et al. 1993). For each experiment amphipods of a similar size were chosen and rinsed briefly in double distilled water. Typically experiments were carried out in $10 \mathrm{l}$ acid-washed plastic tanks with at least 2 replicates of each treatment to avoid pseudo-replication, each tank containing up to 12 amphipods individually housed in perforated plastic containers (Toby 'Teaboys', Aldridge Plastics, Aldridge, UK). In no case was there a statistical difference between replicates of treatments and so replicate data have all been grouped for statistical analysis. Data for any amphipods moulting or dying were excluded from data analysis, thereby explaining the variation in numbers between experiments

Amphipods exposed to radioactively labelled dissolved $\mathrm{Cd}$ or $\mathrm{Zn}$ were counted live at daily intervals for between 4 and $6 \mathrm{~d}$, giving a measure of 'new' (labelled) metal accumulated (see Weeks \& Rainbow 1991). Best fit regression lines were fitted to data for individual amphipods for Days 1 to 4, 5 or 6 inclusive as appropriate, the zero, zero point being excluded to allow for adsorption of labelled metal onto the exoskeleton (see White \& Rainbow 1984, Nugegoda \& Rainbow 1988. 1989a, Rainbow et al. 1993). Accumulation was always linear, so any extra days of exposure simply gave a more confident estimation of the regression coefficient. 
Regression coefficients ( $\mu g g^{-1} \mathrm{~d}^{-1}$ ) represent metal uptake rates of individual amphipods and replicate individual uptake rates were grouped for statistical analysis and calculation of means and standard deviations.

The radioisotopes ${ }^{109} \mathrm{Cd}$ and ${ }^{65} \mathrm{Zn}$ (Amersham International plc, UK) were used as tracers, being added to stock solutions of cadmium and zinc chlorides respectively (Analar grade, BDH) at the concentrations specified below. ${ }^{109} \mathrm{Cd}$ is essentially carrier-free, but total dissolved labelled concentrations of zinc quoted take into account the concentrations of added carrier zinc. Each experimental amphipod was counted live for 1 min at the times detailed below in a Wallac Compugamma gamma counter, after being removed from its container, rinsed in double distilled water and placed in a small glass tube sealed with cling film. At the end of an experiment, each amphipod was frozen, dried to constant weight at $60^{\circ} \mathrm{C}$ and digested in concentrated nitric acid (Aristar grade, $\mathrm{BDH}$ ) at $100^{\circ} \mathrm{C}$. Each digest was made up to a known volume with double distilled water and recounted for correction of the counts which might be affected by geometrical size effects. Corrected live counts were used as measures of labelled metal per unit dry weight of amphipod, and a minimum of 3 corrected live counts used in linear regression analysis by least squares to calculate the regression coefficient of each amphipod - the rate of metal accumulation, or metal uptake. Where a metal uptake rate is quoted, metal uptake was linear in time (significant fit to the linear regression model) over the period of the experiment.

Experiment 1. 24 amphipods, divided between 3 replicate tanks at each concentration, were exposed to each of the following dissolved labelled $\mathrm{Cd}$ concentrations in $33 \% \mathrm{NaCl}\left(500,250,50\right.$ or $1.0 \mu \mathrm{g} \mathrm{Cd}^{-1}$, equivalent to $4.45,2.22,0.44$ or $0.0089 \mu \mathrm{mol} \mathrm{Cd} \mathrm{l}^{-1}$ for $6 \mathrm{~d}$ at $10^{\circ} \mathrm{C}$. Individual amphipods were counted daily.

Experiment 2. Between 30 and 34 amphipods, divided between 3 replicate tanks at each salinity, were exposed to $50 \mu \mathrm{g} \mathrm{l}^{-1}\left(0.44 \mu \mathrm{mol} \mathrm{l}^{-1}\right)$ labelled $\mathrm{Cd}$ for $4 \mathrm{~d}$ at $10^{\circ} \mathrm{C}$ at one of the following salinities: 36.5 , $33,30,27.5,25,20,15$ or $12 \% \mathrm{NaCl}$. Individual amphipods had been taken from a salinity at $33 \%$ $\mathrm{NaCl}$ on Day 0 , and were counted daily.

Experiment 3(a). 24 amphipods were taken from a salinity at $33 \% \mathrm{NaCl}$ (Day 0), divided between 3 replicate tanks at each salinity and exposed to $100 \mu \mathrm{g} \mathrm{l}^{-1}$ $\left(0.89 \mu \mathrm{mol} \mathrm{l}^{-1}\right)$ labelled $\mathrm{Cd}$ for $5 \mathrm{~d}$ at $10^{\circ} \mathrm{C}$ at one of the following salinities: $36.5,33,30,27.5,25,20$ or $15 \%$ $\mathrm{NaCl}$

Experiment 3(b). 24 amphipods were divided between 3 replicate tanks at each salinity, acclimated for $7 \mathrm{~d}$ at $15 \%$ salinity and then exposed to $100 \mu \mathrm{g} \mathrm{l}^{-1}$ $\left(0.89 \mu \mathrm{mol} \mathrm{l}^{-1}\right)$ labelled $\mathrm{Cd}$ for $4 \mathrm{~d}$, all at $10^{\circ} \mathrm{C}$, at one of the following salinities: $36.5,33,30,27.5,25,20$ or $15 \%$ $\mathrm{NaCl}$. Individual amphipods were counted daily.

Experiment 4. 20 amphipods, divided between 2 replicate tanks for each treatment, were exposed to $50 \mu \mathrm{g} \mathrm{l}^{-1}\left(0.76 \mu \mathrm{mol} \mathrm{l^{-1 } )}\right.$ labelled zinc under one of the following treatments for $4 \mathrm{~d}$ at $10^{\circ} \mathrm{C}$ : (1) $30 \% \mathrm{NaCl}$ $\left(920 \mathrm{mOsm} \mathrm{kg}^{-1}\right.$ ), (2) $20 \% \mathrm{NaCl}$ (620 mOsm kg-1), (3) $15 \% \mathrm{NaCl}\left(460 \mathrm{mOsm} \mathrm{kg}{ }^{-1}\right)$, (4) $20 \% \mathrm{NaCl}+61.6 \mathrm{~g} \mathrm{l}^{-1}$ fructose added to change osmolality to $920 \mathrm{mOsm} \mathrm{kg}^{-1}$, the equivalent of $30 \% \mathrm{NaCl}$, and (5) $15 \% \mathrm{NaCl}+30.8 \mathrm{~g}$ $\mathrm{l}^{-1}$ fructose added to change osmolality to $620 \mathrm{mOsm}$ $\mathrm{kg}^{-1}$, the equivalent of $20 \% \mathrm{NaCl}$. Fructose does not complex with either cadmium or zinc at the concentrations added here, and increases osmolality without changing salinity (inorganic content) of the medium.

Experiment 5. A 3-treatment protocol was developed in which amphipods were exposed to labelled cadmium or zinc for 3 d (Treatment 1, Days 0 to 3 ) and their metal uptake rates measured by daily live counting. The amphipods were then exposed for $3 \mathrm{~d}$ (Treatment 2, Days 3 to 7) to a medium without labelled metal, before being exposed again to labelled metal in Treatment 3 (Days 7 to 11 ), again with daily live counting. Between 20 and 30 amphipods, divided between 3 replicate tanks, were exposed at $10^{\circ} \mathrm{C}$ to (A) $100 \mu \mathrm{g} \mathrm{l}^{-1}$ (0.89 $\left.\mathrm{mmol} \mathrm{l}^{-1}\right)$ labelled Cd, or (B) $100 \mu \mathrm{g} \mathrm{I}^{-1}(1.53 \mu \mathrm{mol}$ $\mathrm{l}^{-1}$ ) labelled $\mathrm{Zn}$ in one of five 3-treatment protocols: (a)

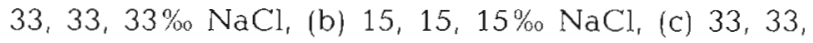
$15 \% \mathrm{NaCl}$ (d) $15,15,33 \% \mathrm{NaCl}$, and (e) $15 \% \mathrm{NaCl}$ plus fructose to raise osmolality to $1010 \mathrm{mOsm} \mathrm{kg}^{-1}$ (the equivalent of $33 \% \mathrm{NaCl}$ ), $15 \% \mathrm{NaCl}$ plus fructose again, $33 \% \mathrm{NaCl}$.

Experiment 6. 25 amphipods were exposed individually to $1 \mathrm{mM} \mathrm{Ca}$ as $\mathrm{CaCl}_{2}$ at $10^{\circ} \mathrm{C}$ in each of the following salinities: $36.5,33,30,20,15$ and $6 \% \mathrm{NaCl}$, after being acclimated for $48 \mathrm{~h}$ to the same salinity. At time zero amphipods were placed in individual $25 \mathrm{ml}$ liquid scintillation vials containing $25 \mathrm{ml} \mathrm{CaCl}_{2}$ at $1 \mathrm{mmol} \mathrm{Ca} \mathrm{kg}{ }^{-1}$ spiked with $1 \mathrm{nCi} \mathrm{ml}^{-1}{ }^{45} \mathrm{Ca}$ dissolved in $\mathrm{NaCl}$ at the appropriate salinity. Five amphipods were removed after $1,2,3,4$ and $5 \mathrm{~h}$. Individual amphipods were rinsed briefly in $\mathrm{NaCl}$ solution of the exposure salinity; dried to constant weight and digested in concentrated nitric acid. Digests were evaporated to dryness and the residue redissolved in $0.5 \mathrm{ml} 1 \mathrm{M} \mathrm{HNO}_{3}$. Then $2 \mathrm{ml}$ scintillation fluid (UltraGold X, Packard) was added and the ${ }^{45} \mathrm{Ca}$ activity counted on a Packard Tricarb 460 liquid scintillation counter. Labelled calcium uptake rates $\left(n \mathrm{~g} \mathrm{~g}^{-1} \mathrm{~h}^{-1}\right)$ of each amphipod were calculated from best fit regression lines relating labelled calcium concentrations (ng $\left.\mathrm{g}^{-1}\right)$ to time $(\mathrm{h})$.

Experiment 7. AWP was measured as the inverse of the half-time of release of tritium-labelled water into unlabelled medium from tritium-labelled amphipods, 
A)


Fig. 1. Orchestia gammarellus. Mean ( \pm 1 SD) (n) accumulated concentrations of labelled $\mathrm{Cd}$ in amphipods exposed to dissolved labelled cadmium at concentrations of (A) $500 \mu \mathrm{g} \mathrm{Cd} \mathrm{l}^{-1}$ (a), $250 \mu \mathrm{g} \mathrm{Cd} \mathrm{l}^{-1}$ (b), and $50 \mu \mathrm{g} \mathrm{Cd} \mathrm{l}^{-1}$ (c) and (B) $50 \mu \mathrm{g} \mathrm{Cd}^{-1}$ (c), and $1 \mu \mathrm{g} \mathrm{Cd} \mathrm{l}^{-1}$ (d) for up to $6 \mathrm{~d}$ at $10^{\circ} \mathrm{C}$ in artificial seawater $(33 \% \mathrm{NaCl})$. Lines drawn are best fit lines through the data presented but uptake rates quoted are means ( \pm 1 SD) of individual uptake rates (Days 1 to 6 ) calculated for each amphipod with at least 3 data points following salinities: $10,15,27.5,33$ and $40 \% \mathrm{NaCl}$.

For each experiment aliquots of $100 \mu \mathrm{l}$ were taken from the unloading flasks of surviving amphipods after $2,4,8,16,30$ and $60 \mathrm{~min}$, and the concentration $\left(\mathrm{C}_{i}\right)$ of THO counted at each time $(t)$. The flasks were then sealed with parafilm (to prevent evaporation of THO) and left overnight to ensure that the THO in the specimen was in equilibrium with the external medium, before a final aliquot was taken to measure the final equilibrium concentration of $\mathrm{THO}\left(\mathrm{C}_{\infty}\right)$ in the medium. All aliquots were counted for tritium activity in a liquid scintillation cocktail (UltraGold X, Packard) on a Packard Tricarb 460 liquid scintillation counter. The whole procedure was carried out at $10^{\circ} \mathrm{C}$. To determine the halftime of unloading, $\log \left(\mathrm{C}_{\infty}-\mathrm{C}_{t}\right)$ was plotted against time for each amphipod and a regression line fitted to the data. The time taken for half of body water to be exchanged with the external medium was calculated from the regression equation at $x=\log C_{\infty}-\log 2$.

Experiment 8. 12 amphipods were exposed to (A) $100 \mathrm{\mu g} \mathrm{l}^{-1}\left(0.89 \mathrm{\mu mol} \mathrm{l}^{-1}\right)$ labelled $\mathrm{Cd}$, or (B) $100 \mu \mathrm{\mu g} \mathrm{l}^{-1}$ $\left(1.53 \mu \mathrm{mol} \mathrm{l}^{-1}\right)$ labelled $\mathrm{Zn}$ at $10^{\circ} \mathrm{C}$ in each of 4 salinities: (a) 33, (b) 27.5, (c) 15 or (d) $6 \% \mathrm{NaCl}$ for $3 \mathrm{~d}$, before being placed in the same salinity without labelled metal for a further $3 \mathrm{~d}$. Individual amphipods were counted live daily.

\section{RESULTS}

\section{Experiment 1}

Experiment $7(\mathrm{a})$. After a $72 \mathrm{~h}$ pre-exposure acclimation period at one of the following $\mathrm{NaCl}$ salinities: 6 , $10,15,27.5,30,33,35$ and $40 \% \mathrm{NaCl}_{1} 11$ amphipods were subjected to tritium-loading for $24 \mathrm{~h}$ in tritiated water (THO; specific activity $=5 \mu \mathrm{Ci} \mathrm{ml}^{-1}{ }^{3} \mathrm{H}$ ) at the same salinity. Each amphipod was rinsed thoroughly with $\mathrm{NaCl}$ of the appropriate salinity, and placed (time zerol in a conical flask containing $100 \mathrm{ml}$ of $\mathrm{NaCl}$ of that salinity to effect unloading of THO.

Experiment $\mathbf{7 ( b )} .5$ batches of 11 amphipods were individually pre-exposed to $27.5 \% \mathrm{NaCl}$ for $72 \mathrm{~h}$ before being loaded with tritium in THO $(5 \mu \mathrm{Ci} \mathrm{ml})^{-1}$ ${ }^{3} \mathrm{H}$ ) again at $27.5 \% \mathrm{NaCl}$. Each amphipod was rinsed thoroughly with $27.5 \% \mathrm{NaCl}$ and each batch of 11 amphipods unloaded individually in $\mathrm{NaCl}$ at one of the
Fig. 1 shows the accumulation of radioactively labelled cadmium by amphipods exposed to 4 concentrations of dissolved labelled cadmium for up to $6 \mathrm{~d}$. At all concentrations the labelled cadmium is accumulated linearly, and uptake rates (measured as accumulation rates) are given for each exposure. The lines drawn (Fig. 1) are best fit lines through the data presented whereas the figures quoted for mean cadmium uptake rates are actually the means of individual uptake rates (Days 1 to 6) calculated for each amphipod having allowed for adsorption (Days 0 to 1 ), as indicated by the intercept of the $y$-axis (White \& Rainbow 1984, Nugegoda \& Rainbow 1988, 1989a, Rainbow et al. 1993). 


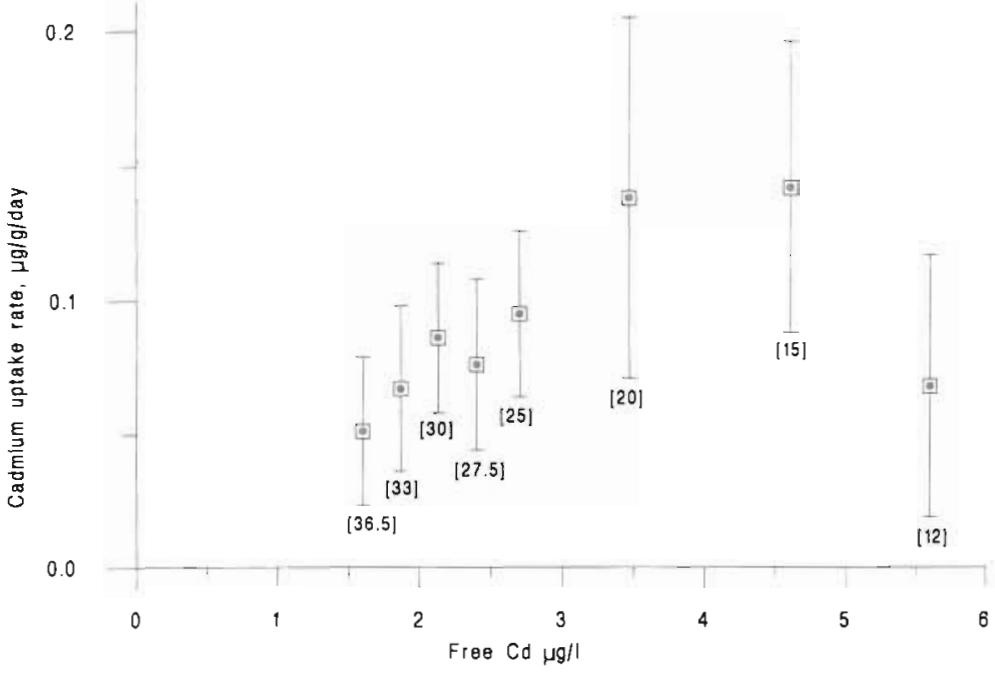

Fig. 2. Orchestia gammarellus. Changes in the mean ( \pm 1 SD) rate of uptake of labelled cadmium ( $\mu \mathrm{g} \mathrm{g}^{-1} \mathrm{~d}^{-1}$ ) by amphipods as a function of free labelled $\mathrm{Cd}^{2+}$ ion concentration $\left(\mu \mathrm{gl}^{-1}\right.$ ) as altered by changes in salinity $1 \%$ $\mathrm{NaCl}]$ when exposed to $50 \mu \mathrm{g} \mathrm{1^{-1 }}$ total labelled $\mathrm{Cd}$ for $4 \mathrm{~d}$ at $10^{\circ} \mathrm{C}$. Data for salinities between 36.5 and $20 \%$ fit the regression line $y=-0.017+0.034 x$ $\left(\mathrm{r}^{2}=0.93, \mathrm{p}=0.002\right) \mathrm{n}=24$ to 29 at each salinity. Amphipods were transferred directly from $33 \% \mathrm{NaCl}$ on Day 0 at $50 \mu \mathrm{g} \mathrm{I}^{-1}$ total labelled cadmium, as op-

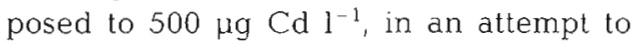
investigate whether saturation of any enzyme-driven process is in evidence. The opportunity was also taken to extend the reduction in salinity down to $12 \% \mathrm{NaCl}$. Cadmium uptake rates show great individual variability and increase with the free $\mathrm{Cd}^{2+}$ ion concentration in salinities down to $20 \% \mathrm{NaCl}$. The cadmium uptake rate levels off between 20 and $15 \% \mathrm{NaCl}$ in spite of a rise in the free labelled $\mathrm{Cd}^{2+}$ ion concentration released from chloride complexation from 3.5 to $4.6 \mu \mathrm{g} \mathrm{Cd}^{2+} l^{-1}$. The labelled cadmium uptake rate then drops at $12 \%$ $\mathrm{NaCl}$, the free labelled $\mathrm{Cd}^{2+}$ concentration having risen further to $5.6 \mu \mathrm{g} \mathrm{Cd}^{2+} \mathrm{l}^{-1}$.

The pattern of change of cadmium uptake rate with salinity change between 36.5 and $15 \%$ NaCl is thus the same at 50 and $500 \mu \mathrm{g} \mathrm{Cd} \mathrm{l}^{-1}$, and is therefore independent of the cadmium concentration, total or free ion.
Uptake rates increase with cadmium exposure and it is relevant to note that cadmium uptake shows the expected proportional increase between exposures of 250 and $500 \mu \mathrm{g} \mathrm{Cd} \mathrm{l}^{-1}$. Thus, cadmium uptake shows no sign of saturation even at $500 \mu \mathrm{g} \mathrm{I}^{-1}$ total cadmium (18.7 $\mathrm{\mu g} \mathrm{l}^{-1}$ free $\mathrm{Cd}^{2+}$ ion). If cadmium uptake were to be interpreted in terms of a saturable enzyme-powered mechanism, then this amount of cadmium is insufficient to saturate the system. A plot of cadmium uptake rate against metal concentration (both in log scales) is in fact linear and confirms to the Freundlich expression $y=0.00217 x^{0.931}\left(\mathrm{r}^{2}=\right.$ $0.986)$, the coefficient (0.931) approaching 1 indicating that metal uptake is essentially passive under these physico-chemical conditions without an enzyme-driven component

Fig. 1 also shows that lower exposures of 50 or $100 \mathrm{\mu g} \mathrm{l}^{-1}$ total cadmium would provide uptake data measurable in the time period, with adsorption being saturated within Day 1 (note back extrapolation of lines to intersect the $y$-axis - see Rainbow et al. 1993) and not therefore obscuring uptake and accumulation of cadmium into the body.

\section{Experiment 2}

Expt 2 (Fig. 2) repeats the experiment carried out by Rainbow et al. (1993) but over $4 \mathrm{~d}$

\section{Experiment 3}

A repeat experiment over $5 \mathrm{~d}$ at $100 \mu \mathrm{g} \mathrm{l}^{-1}$ total labelled cadmium (Fig. 3) confirms the pattern established at $500 \mu \mathrm{g} \mathrm{Cd} \mathrm{l}^{-1}$ (Rainbow et al. 1993) and $50 \mu \mathrm{g}$

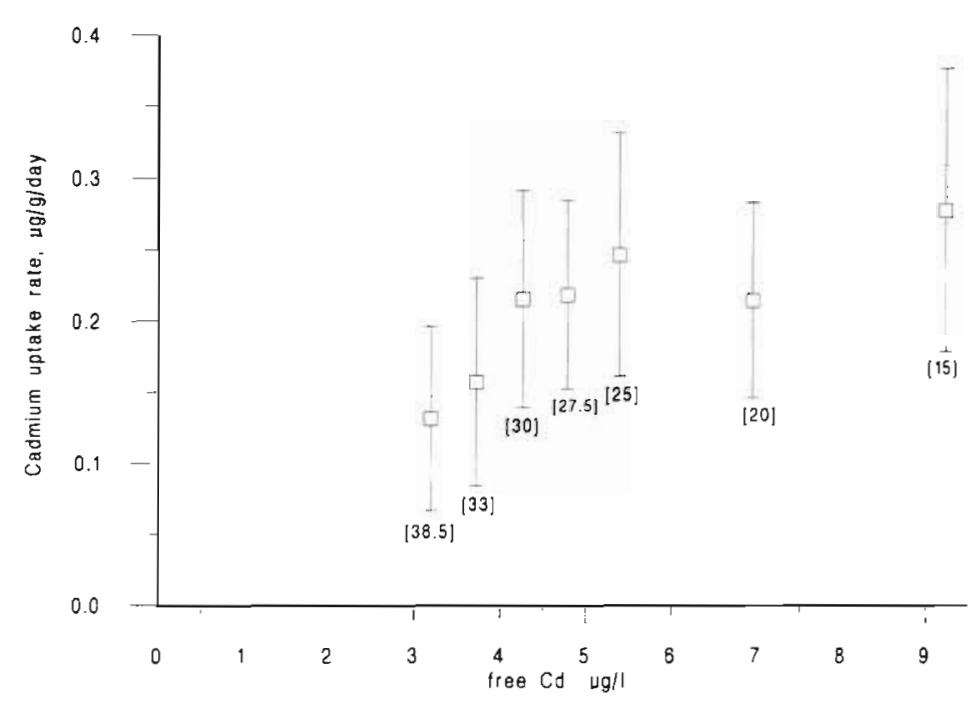

Fig. 3. Orchestia gammarellus. Changes in the mean ( $\pm 1 \mathrm{SD}$ ) rates of uptake of labelled cadmium ( $\mu \mathrm{g} \mathrm{g}^{-1} \mathrm{~d}^{-1}$ ) by amphipods as a function of the labelled $\mathrm{Cd}^{2+}$ ion concentration $\left(\mu \mathrm{gl}^{-1}\right.$ ) as altered by changes in salinity [\% $\mathrm{NaCl}$ ] when exposed to $100 \mathrm{\mu g} \mathrm{l}^{-1}$ total labelled $\mathrm{Cd}$ for $5 \mathrm{~d}$ at $10^{\circ} \mathrm{C}$. Data for salinities between 36.5 and $25 \%$ fit the regression line $y=$ $-0.034+0.053 \times\left(r^{2}=0.93, p=0.008\right) . n=18$ to 22 at each salinity Amphipods were transferred directly from $33 \% \mathrm{NaCl}$ on Day 0 


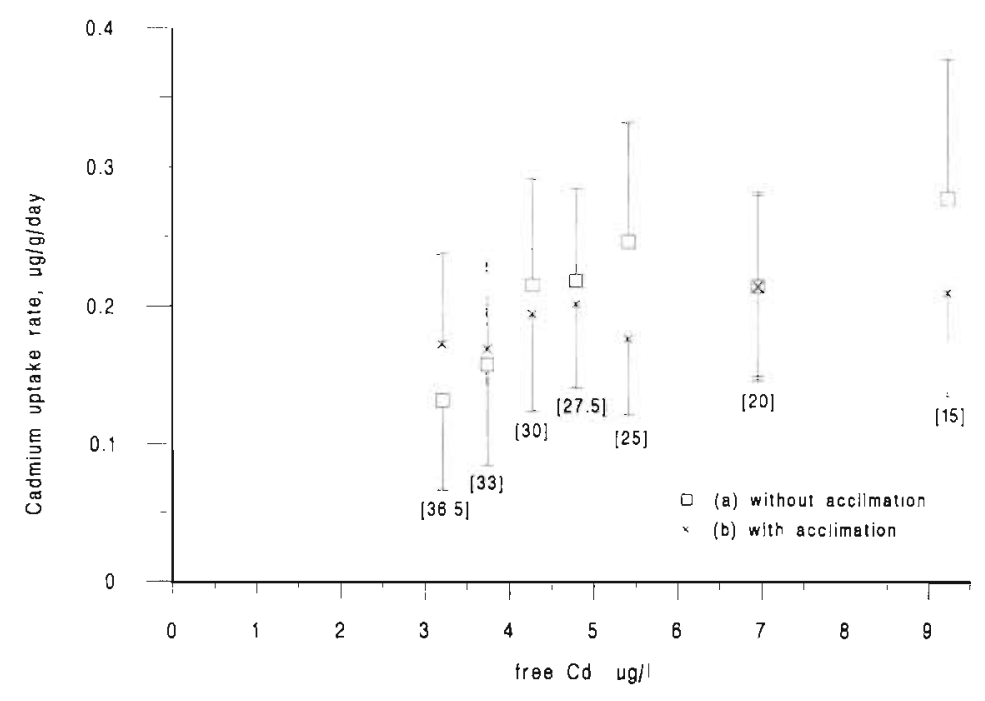

Fig. 4. Orchestia gammarellus. Mean ( $\pm 1 \mathrm{SD}$ ) rates of uptake of labelled cadmium by amphipods as a function of free $\mathrm{Cd}^{2+}$ ion concentration as altered by changes in salinity [\% $\mathrm{NaCl}]$ when exposed to $100 \mathrm{\mu g} \mathrm{l}^{-1}$ total labelled $\mathrm{Cd}$ at $10^{\circ} \mathrm{C}$. Amphipods were either (a) transferred directly from $33 \% \mathrm{NaCl}$ on Day 0 ( $\mathrm{n}=18$ to 22), or (b) acclimated to $15 \% \mathrm{NaCl}$ for $7 \mathrm{~d}$ before transfer on Day 0 ( $\mathrm{n}=14$ to 22 )

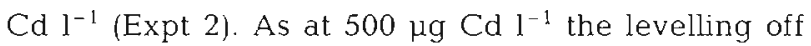
occurs between salinities of 25 and $20 \% \mathrm{NaCl}$. There is great individual variability apparent at all 3 cadmium exposures, and it is likely that the exact point of levelling off is similarly variable between batches of amphipods used in experiments.

This experiment also attempted to define the effect of acclimation of the amphipods on the patterns observed above. The amphipods depicted in Fig. 3 were transferred to the salinity quoted directly from a salinity of $33 \% \mathrm{NaCl}$ at Day 0 , the start of the $5 \mathrm{~d}$ experiment. Given that the initiation of the proposed physiological response occurs within $4 \mathrm{~d}$ in the above experiments, an equivalent batch of amphipods was acclimated to $15 \%$ o $\mathrm{NaCl}$ for $7 \mathrm{~d}$ before transfer on Day 0 to the experimental salinity for exposure for $4 \mathrm{~d}$ to $100 \mathrm{\mu g} \mathrm{l}^{-1}$ total labelled cadmium. Fig. 4 shows a comparison of the labelled cadmium uptake rates of the acclimated and non-acclimated amphipods.

The results of the comparison in Fig. 4 are difficult to interpret given their wide variability (note large values of $n$ ), but appear to show no consistent differences. It appears therefore that acclimation to $15 \% \mathrm{NaCl}$ for $7 \mathrm{~d}$ has not caused a permanent physiological change such as might cause a decrease in cadmium up- take rates at $33 \% \mathrm{NaCl}$ in comparison with non-acclimated amphipods.

\section{Experiment 4}

Table 1 gives results of experiments measuring the uptake rates of zinc from $50 \mu \mathrm{g} \mathrm{Zn}$ $1^{-1}$ at 3 salinities $(30,20$ and $15 \%$ NaCl), but also under 2 conditions in which fructose has been added to change the total osmolality of the solution without a concomitant change in the salinity and concentration of inorganic ions including chloride. Induction of any physiological effect at low salinity reducing trace metal uptake, as has been inferred from the experiments above, should be caused by changes in osmolality only.

As expected from the interpretation above, zinc uptake rates are equal at 15 and $20 \%$ $\mathrm{NaCl}$, both being significantly higher than that at $30 \% \mathrm{NaCl}$. At $20 \% \mathrm{NaCl}$, increased osmolality to match that at $30 \% \mathrm{NaCl}$ has had no effect on zinc uptake rate (compare treatments 2 and 4 ) - to be expected if no physiological response is as yet switched on at $20 \% \mathrm{NaCl}$. At $15 \% \mathrm{NaCl}$ on the other hand the increased osmolality resulting from the presence of fructose has had an effect. The zinc uptake rate is higher at $15 \% \mathrm{NaCl}$ if fructose is present (treatments 3 and 5); i.e. the decreased osmolality associated with $15 \% \mathrm{NaCl}$ (in the absence of fructose) has initiated the physiological response which now counteracts the effect of speciation changes promoting zinc uptake.

Table 1. Orchestia gammarellus. Mean uptake rates of $\mathrm{Zn}( \pm 1 \mathrm{SD})$ from $50 \mu \mathrm{g} \mathrm{Zn} \mathrm{^{-1 }}$ in 5 treatments of osmolality/salinity, and selected statistical comparisons of treatments by ANOVA (ns: $\mathrm{p}>0.05$ )

\begin{tabular}{|c|c|c|c|c|c|}
\hline Treatment & $\begin{array}{c}\text { Salinity } \\
(\% \mathrm{NaCl})\end{array}$ & $\begin{array}{c}\text { Osmolality } \\
\left(\mathrm{mOsm} \mathrm{kg}^{-1}\right)\end{array}$ & $\begin{array}{l}\text { Free } Z^{2+} \\
\left(\mu \mathrm{g} \mathrm{l}^{-1}\right)\end{array}$ & $\begin{array}{l}\text { Zn uptake rate } \\
\left(\mu g \mathrm{Zn} \mathrm{g}^{-1} \mathrm{~d}^{-1}\right)\end{array}$ & $\mathrm{n}$ \\
\hline 1 & 30 & 920 & 35.0 & $1.25 \pm 0.19$ & 20 \\
\hline 2 & 20 & 620 & 38.8 & $1.75 \pm 0.39$ & 20 \\
\hline 3 & 15 & 460 & 40.5 & $1.75 \pm 0.40$ & 19 \\
\hline 4 & 20 plus fructose & 920 & 38.8 & $1.60 \pm 0.18$ & 18 \\
\hline 5 & 15 plus fructose & 620 & 40.5 & $2.18 \pm 0.37$ & 20 \\
\hline \multicolumn{6}{|c|}{$\begin{array}{c}\text { Comparisons by ANOVA: } \\
\qquad F\end{array}$} \\
\hline 1 vs 2 & 23.75 & 1,92 & & $<0.002$ & \\
\hline 1 vs 3 & 22.96 & 1,92 & & $<0.001$ & \\
\hline 2 vs 3 & 0.00 & 1,92 & & ns & \\
\hline 2 vs 4 & 2.10 & 1,92 & & ns & \\
\hline 3 vs 5 & 16.73 & 1,92 & & $<0.001$ & \\
\hline 4 vs 5 & 29.87 & 1,92 & & $<0.001$ & \\
\hline
\end{tabular}



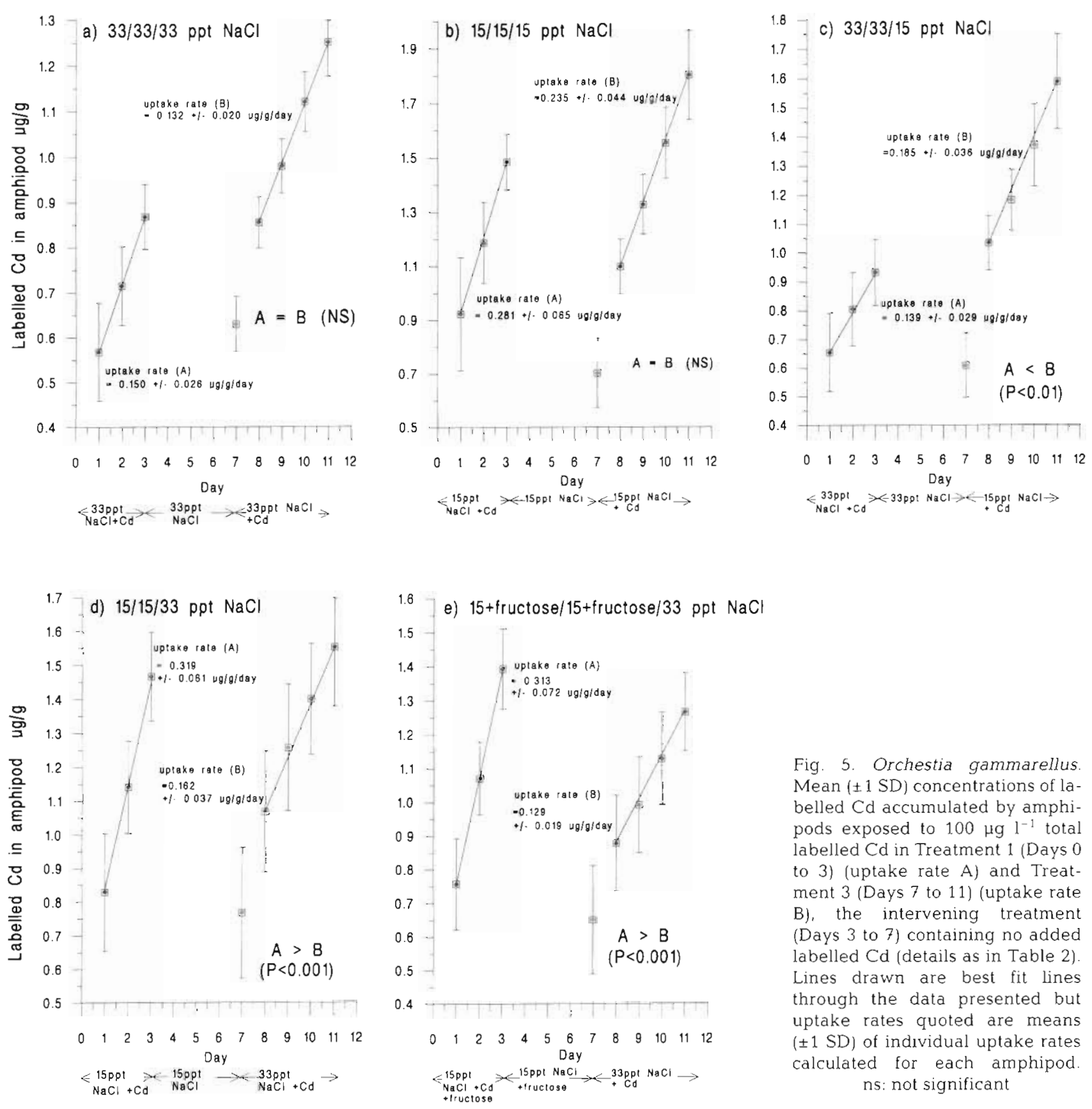

Fig. 5. Orchestia gammarellus. Mean ( \pm 1 SD) concentrations of labelled $\mathrm{Cd}$ accumulated by amphipods exposed to $1.00 \mathrm{Hg} \mathrm{l}^{-1}$ total labelled $\mathrm{Cd}$ in Treatment 1 (Days 0 to 3) (uptake rate A) and Treatment 3 (Days 7 to 11) (uptake rate B), the intervening treatment (Days 3 to 7 ) containing no added labelled Cd (details as in Table 2) Lines drawn are best fit lines through the data presented but uptake rates quoted are means ( \pm 1 SD) of induvidual uptake rates calculated for each amphipod. ns: not significant

\section{Experiment 5}

Given the variability between trace metal uptake rates of individual amphipods, particularly between batches of amphipods, a new protocol was developed whereby the metal uptake rates of the same amphipods would be measured under different physicochemical conditions (see 'Materials and methods').

Fig. 5 and Table 2 give the results of experiments wherein amphipods were exposed to $100 \mathrm{\mu g} \mathrm{l}^{-1}$ labelled $\mathrm{Cd}$ for $3 \mathrm{~d}$ under one set of physico-chemical conditions (Treatment 1 ) and cadmium uptake rate measured; the amphipods were then exposed to a second treatment without labelled Cd (Days 3 to 7 ), and finally to a third treatment (Days 7 to 11 ) with labelled cadmium for measurement of the new cadmium uptake rate.

The first 2 comparisons (Fig $5 \mathrm{a}, \mathrm{b}$ ) confirm (Table 2) that the protocol is acceptable; there is no difference between uptake rates measured under identical physico- 
Table 2. Orchestia gammarellus. Comparisons by ANOVA of mean Cd uptake rates ( $\pm 1 \mathrm{SD}$ ) of amphipods exposed to $100 \mu \mathrm{g}$ Cd $\mathrm{I}^{-1}$ in Treatment 1 (Days 0 to 3) and Treatment 3 (Days 7 to 11), the intervening Treatment 2 (Days 3 to 7 ) containing no added Cd. Addition of fructose to $15 \% \mathrm{NaCl}$ increases osmolality from 460 to $1010 \mathrm{mOsm} \mathrm{kg}^{-1}$, equivalent to that of $33 \% \mathrm{NaCl}$. ns: p >0.05

\begin{tabular}{|c|c|c|c|c|c|c|c|c|}
\hline \multirow[t]{2}{*}{ Treatment 1} & \multirow[t]{2}{*}{ Treatment 2} & \multirow[t]{2}{*}{ Treatment 3} & \multicolumn{2}{|c|}{ Cd uptake rates $\left(\mathrm{\mu g} \mathrm{g}^{-1} \mathrm{~d}^{-1}\right)$} & \multirow[t]{2}{*}{$\mathrm{n}$} & \multicolumn{3}{|c|}{ ANOVA } \\
\hline & & & Treatment 1 & Treatment 3 & & F & df & $\mathrm{p}$ \\
\hline $33 \% \mathrm{NaCl}$ & $33 \% \mathrm{NaCl}$ & $33 \% \mathrm{NaCl}$ & $0.150 \pm 0.026$ & $0.132 \pm 0.020$ & 8 & 2.37 & 1,14 & ns \\
\hline $15 \% \mathrm{NaCl}$ & $15 \% \mathrm{NaCl}$ & $15 \% \mathrm{NaCl}$ & $0.281 \pm 0.065$ & $0.235 \pm 0.044$ & 10 & 3.40 & 1,18 & ns \\
\hline $33 \% \mathrm{NaCl}$ & $33 \% \mathrm{NaCl}$ & $15 \% \mathrm{NaCl}$ & $0.139 \pm 0.029$ & $0.185 \pm 0.036$ & 9 & 9.18 & 1,16 & $<0.01$ \\
\hline $15 \% \mathrm{NaCl}$ & $15 \% \mathrm{NaCl}$ & $33 \% \mathrm{NaCl}$ & $0.319 \pm 0.061$ & $0.162 \pm 0.037$ & 7 & 34.1 & 1,12 & $<0.001$ \\
\hline $\begin{array}{l}15 \% \mathrm{NaCl} \\
\text { plus fructose }\end{array}$ & $\begin{array}{c}15 \% \mathrm{NaCl} \\
\text { plus fructose }\end{array}$ & $33 \% \mathrm{NaCl}$ & $0.313 \pm 0.072$ & $0.129 \pm 0.019$ & 11 & 82.0 & 1,20 & $<0.001$ \\
\hline
\end{tabular}

chemical conditions. The third and fourth comparisons (Fig. 5c, d) confirm the now expected difference between cadmium uptake rates at 33 and $15 \% \mathrm{NaCl}_{1}$ irrespective of order of exposure. The final comparison (Fig. 5e) compares physico-chemical conditions of equal total osmolality but different salinity. There is a significant difference between cadmium uptake rates of amphipods exposed to $33 \% \mathrm{NaCl}$ and those exposed to a different salinity $15 \% \mathrm{NaCl}$ but the same osmolality (1010 mOsm kg-1) caused by the addition of fructose.

Fig. 6 and Table 3 show the results of similar experiments in which amphipods were exposed to $100 \mathrm{\mu g} \mathrm{l}^{-1}$ labelled $\mathrm{Zn}$. As expected, exposures under the same physico-chemical conditions produced no differences in zinc uptake rates (Table 3), confirming that the extra handling did not change rates being measured, thereby validating the protocol. In contrast to the case of cadmium (Table 2), the change from 33 to $15 \% \mathrm{NaCl}$ did not produce a significant change in zinc uptake rate, nor did the change from 15 to $33 \% \mathrm{NaCl}$ (Table 3 ).

\section{Experiment 6}

Fig. 7 shows the effect of decreasing salinity on the uptake of calcium by Orchestia gammarellus from $1 \mathrm{mM}$ (ca $2 \mathrm{~g} \mathrm{~kg}^{-1}$ ) calcium. This calcium concentration is one-tenth of that of seawater in order to ensure a minimal effect of calcium on total salinity and to stimulate the activity of any calcium pump.

The calcium uptake rate increases with decreased salinity.

\section{Experiment 7}

The half-time of release of tritium-labelled water into unlabelled medium from tritium-labelled amphipods is an inverse measure of AWP. Thus a high halftime indicates a low AWP.

Table 4A gives the AWP of amphipods pre-exposed and loaded with tritium (1 d) in the same salinity as the medium in which the AWP was measured. Interindividual variability is high, but AWP did not change between 10 and $33 \% \mathrm{NaCl}$ although it was reduced at very low $(6 \% \mathrm{NaCl})$ and high $(37.5 \% \mathrm{NaCl})$ salinities.

In amphipods pre-exposed and loaded with tritium in $27.5 \% \mathrm{NaCl}$ (Table $4 \mathrm{~B}$ ), there was little change in AWP in media of salinities between 10 and $40 \%$. It therefore appears that changes in AWP are not themselves sufficient to explain the negative physiological effect countering any physico-chemical and major ion uptake rate promotion of trace metal uptake at salinities below $20 \% \mathrm{NaCl}$.

Table 3. Orchestia gammarellus. Comparisons by ANOVA of mean $\mathrm{Zn}$ uptake rates ( $\pm 1 \mathrm{SD}$ ) of amphipods exposed to $100 \mu \mathrm{g} \mathrm{Zn}$ $\mathrm{I}^{-1}$ in Treatment 1 (Days 0 to 3) and Treatment 3 (Days 7 to 11), the intervening Treatment 2 (Days 3 to 7 ) containing no added $\mathrm{Zn}$. Addition of fructose to $15 \%$ increases osmolality from 460 to $1010 \mathrm{mOsm}^{-1}$, equivalent to that of $33 \% \mathrm{NaCl}$. ns: p $>0.05$

\begin{tabular}{|c|c|c|c|c|c|c|c|c|}
\hline \multirow{2}{*}{ Treatment 1} & \multirow{2}{*}{ Treatment 2} & \multirow{2}{*}{ Treatment 3} & \multicolumn{2}{|c|}{ Zn uptake rates $\left(\mu \mathrm{g} \mathrm{g}^{-1} \mathrm{~d}^{-1}\right)$} & \multirow[t]{2}{*}{$\mathrm{n}$} & \multicolumn{3}{|c|}{ ANOVA } \\
\hline & & & Treatment 1 & Treatment 3 & & $F$ & df & $\mathrm{p}$ \\
\hline $33 \% \mathrm{NaCl}$ & $33 \% \mathrm{NaCl}$ & $33 \% \mathrm{NaCl}$ & $1.34 \pm 0.23$ & $1.21 \pm 0.13$ & 10 & 2.59 & 1,18 & ns \\
\hline $15 \%$ & $15 \%$ & $15 \%$ & $2.13 \pm 0.49$ & $1.98 \pm 0.23$ & 10 & 0.68 & 1,18 & ns \\
\hline $33 \%$ & $33 \%$ & $15 \%$ & $1.59 \pm 0.33$ & $1.44 \pm 0.45$ & 12 & 0.88 & 1,22 & ns \\
\hline $15 \%$ & $15 \%$ & $33 \%$ & $1.94 \pm 0.49$ & $1.88 \pm 0.45$ & 12 & 0.12 & 1,22 & ns \\
\hline $\begin{array}{c}15 \% \\
\text { plus fructose }\end{array}$ & $\begin{array}{c}15 \% \\
\text { plus fructose }\end{array}$ & $33 \%$ & $1.92 \pm 0.59$ & $1.50 \pm 0.23$ & 10 & 4.46 & 1,18 & $<0.05$ \\
\hline
\end{tabular}



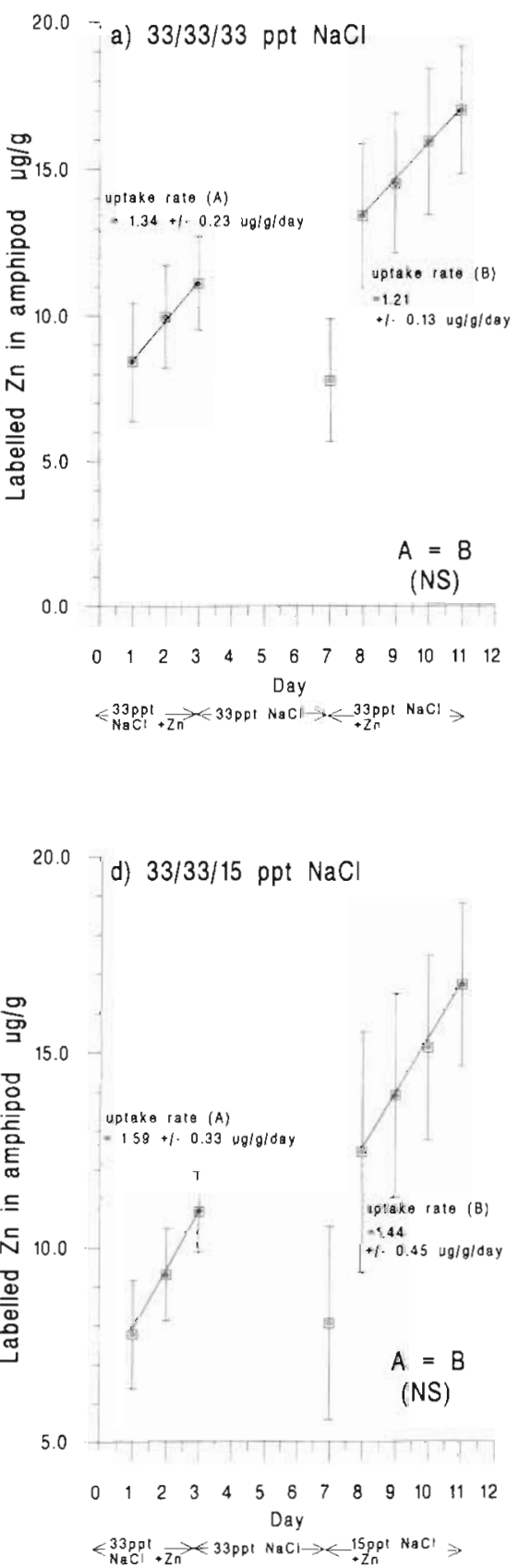

\section{Experiment 8}

Clearly it is necessary to seek another physiological explanation of the apparent reductions in cadmium and zinc uptake rates at salinites below $20 \% \mathrm{NaCl}$. A possible clue lies in the data presented in Figs. $5 \& 6$.

It is known that Orchestia gammarellus does not excrete zinc taken up from solution at $33 \% \mathrm{NaCl}$ (Weeks \& Rainbow 1991). Thus the pattern of accumulation of labelled zinc in Fig. 6a can be explained as follows:
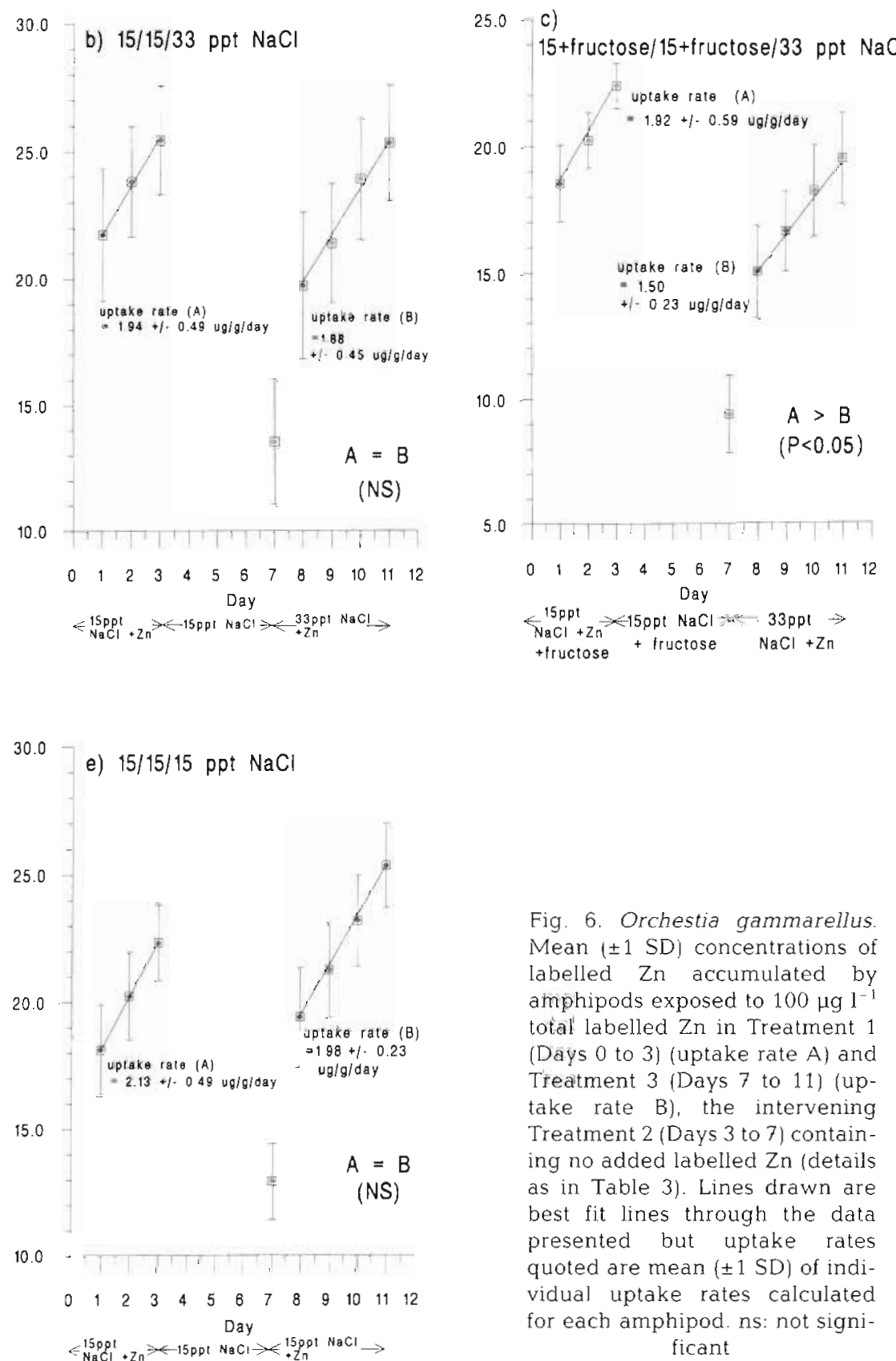

Fig. 6. Orchestia gammarellus Mean $( \pm 1 \mathrm{SD})$ concentrations of labelled $\mathrm{Zn}$ accumulated by amphipods exposed to $100 \mu \mathrm{g} \mathrm{l^{-1 }}$ total labelled $\mathrm{Zn}_{n}$ in Treatment 1 (Days 0 to 3 ) (uptake rate $A$ ) and Treatment 3 (Days 7 to 11) (uptake rate $B$ ), the intervening Treatment 2 (Days 3 to 7 ) containing no added labelled $\mathrm{Zn}$ (details as in Table 3). Lines drawn are best fit lines through the data presented but uptake rates quoted are mean $( \pm 1$ SD) of individual uptake rates calculated for each amphipod. ns: not significant
Days 0 to 1 Adsorption of labelled zinc onto the exoskeleton (estimated by back extrapolation of accumulation line to be ca $7 \mu \mathrm{g} \mathrm{g}^{-1}$ — see Rainbow et al. 1993) plus uptake (equivalent to accumulation) into the body $\left(1.34 \mu \mathrm{g} \mathrm{g}^{-1} \mathrm{~d}^{-1}\right)$

Days 1 to 3: Uptake (accumulation) into the body (1.34 $\left.\mu \mathrm{g} \mathrm{g}^{-1} \mathrm{~d}^{-1}\right)$.

Days 3 to 7: Desorption of some adsorbed zinc into unlabelled medium (ca $3 \mu \mathrm{g} \mathrm{g}^{-1}$ ).

Days 7 to 11 Resaturation of adsorption of zinc plus 
Table 4. Orchestia gammarellus. Apparent water permeability (AWP) as measured by half-time of tritiated water exchange (unloading) into tritium-free medium, after different treatments of pre-exposure $(72 \mathrm{~h}$ ) and loading ( $24 \mathrm{~h})$

\begin{tabular}{|ccccr|}
$\begin{array}{c}\text { Pre-exposure } \\
(72 \mathrm{~h}) \\
\text { salinity }(\%)\end{array}$ & $\begin{array}{c}\text { Loading } \\
(24 \mathrm{~h}) \\
\text { salinity }(\%)\end{array}$ & $\begin{array}{c}\text { Unloading } \\
\text { salinity } \\
(\%)\end{array}$ & $\begin{array}{c}\text { Half-time } \\
\text { mean } \pm 1 \mathrm{SD} \\
(\mathrm{min})\end{array}$ & $\mathrm{n}$ \\
\hline $\begin{array}{c}\text { (A) Same salinity } \\
\text { throughout }\end{array}$ & & & \\
6 & 6 & 6 & $34.5 \pm 6.4$ & 4 \\
10 & 10 & 10 & $21.5 \pm 3.3$ & 7 \\
15 & 15 & 15 & $25.3 \pm 5.4$ & 11 \\
27.5 & 27.5 & 27.5 & $23.7 \pm 6.4$ & 11 \\
30 & 30 & 30 & $28.6 \pm 6.6$ & 10 \\
33 & 33 & 33 & $21.7 \pm 4.8$ & 10 \\
35 & 35 & 35 & $33.3 \pm 4.4$ & 5 \\
40 & 40 & 40 & 28.0 & 1 \\
& & & & \\
(B) Pre-exposure and loading at $27.5 \%$ & & \\
27.5 & 27.5 & 10 & $20.7 \pm 5.6$ & 7 \\
27.5 & 27.5 & 15 & $22.1 \pm 6.6$ & 7 \\
27.5 & 27.5 & 27.5 & $23.9 \pm 6.7$ & 10 \\
27.5 & 27.5 & 33 & $19.5 \pm 3.3$ & 9 \\
27.5 & 27.5 & 40 & $24.3 \pm 10.4$ & 8 \\
\hline
\end{tabular}

continuing uptake (accumulation) into body $(1.21 \mathrm{\mu g}$ $\mathrm{g}^{-1} \mathrm{~d}^{-1}$ ), there being no significant difference in zinc uptake rates between Days 1 to 3 and 7 to 11 (Fig. 6a).

A similar explanation would hold for cadmium (Fig. 5a).

However the pattern is clearly altered at $15 \% \mathrm{NaCl}$ for both zinc (Fig. 6b) and cadmium (Fig. 5b). A com-

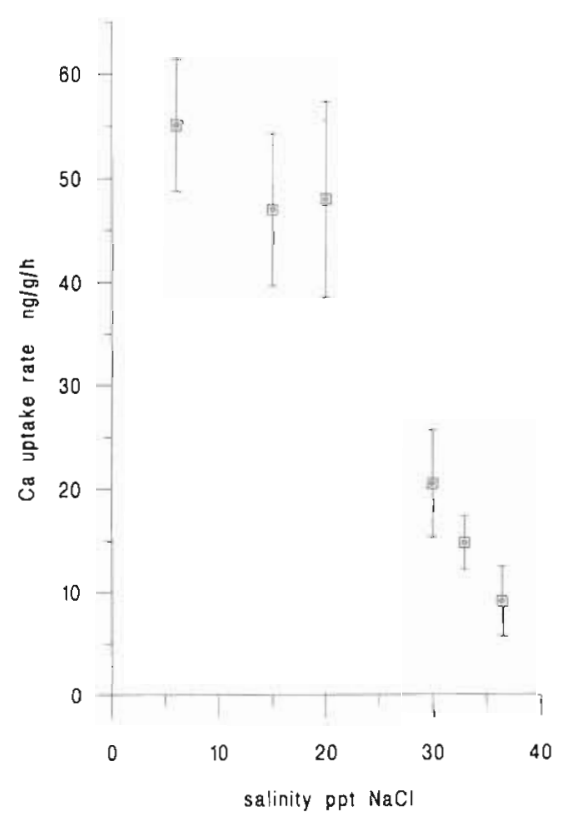

Fig. 7 Orchestia gammarellus. Mean rate of uptake of calcium (ng g $\mathrm{g}^{-1} \mathrm{~h}^{-1} \pm 1 \mathrm{SD}, \mathrm{n}=5$ ) of amphipods exposed to $1 \mathrm{mM}$ $\mathrm{Ca}^{2+}$ in media of a range of salinities (\%o $\mathrm{NaCl}$ ) at $10^{\circ} \mathrm{C}$ parison between accumulated labelled metal concentrations on Days 3 and 8 suggests that more accumulated metal has been lost than is accountable by desorption alone (note the failure of resaturation of adsorption to return body metal concentrations to Day 3 values, cf. Figs. 5 a \& 6a). It seems possible therefore that the amphipods actually excrete accumulated metals at $15 \%$ NaCl, known not to be the case at $33 \%$ $\mathrm{NaCl}$. If this was 5o, then accumulated metal concentrations would no longer be a measure of absolute uptake at low salinities.

This experiment was therefore designed to test whether accumulated cadmium and zinc concentrations could be excreted at low salinities. Figs. 8 \& 9 show patterns of metal accumulation and loss at a range of salinities. The patterns of both cadmium and zinc accumulation at $33 \% \mathrm{NaCl}$ indicate desorption only, as expected, whereas at $15 \% \mathrm{NaCl}$ the continuing decreases in cadmium (Fig 8c) and zinc (Fig. 9c) between Days 3 and 5 do suggest that excretion is also occurring. The pattern for cadmium at $27.5 \% \mathrm{NaCl}$ (Fig. 8b) indicates desorption only, as probably does that for zinc (Fig. 9b). Enigmatically, neither pattern at $6 \% \mathrm{NaCl}$ provides any suggestion of excretion (Figs. 8 \& 9).

\section{DISCUSSION}

The first 3 experiments on cadmium uptake by the amphipod Orchestia gammarellus confirmed that the effect of salinity on the uptake of cadmium observed by Rainbow et al. (1993) was not a manifestation of the saturation of an enzyme-powered uptake system. Rainbow et al. (1993) had exposed O. gammarellus to $500 \mu \mathrm{g} \mathrm{l}^{-1}$ total cadmium and $100 \mu \mathrm{g} \mathrm{l}^{-1}$ total zinc at a range of salinities and had shown a levelling off of the uptake rate of each metal between 25 and $15 \%$. This levelling off is unexpected if the trace metal uptake rate is controlled physico-chemically by the concentration of the dissolved free metal ion, in each case still increasing between 25 and 15\% (Rainbow et al. 1993).

It could be argued that in each case the availability of the free metal ion (increasing with decreasing inorganic complexation) had reached such a value (ca 28

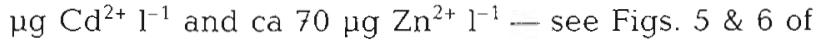
Rainbow et al. 1993) as to saturate an enzyme-driven uptake system. The cadmium uptake experiments described here refute this argument, not least the coefficient in the Freundlich expression which is close to 1. In Expt 1, cadmium uptake rates by Orchestia gammarellus continued to increase proportionately between total exposures at 200 and $500 \mu \mathrm{g} \mathrm{l}^{-1}$ total cadmium (9.3 and $18.7 \mu \mathrm{g} \mathrm{Cd}^{2+} 1^{-1}$ respectively), from 0.46 to $0.77 \mu g \mathrm{Cd} \mathrm{g}^{-1} \mathrm{~d}^{-1}$ (Fig. 1). Nevertheless apparent 
saturation of the rate of uptake of labelled cadmium occurred at only about $0.14 \mu \mathrm{g} \mathrm{Cd} \mathrm{g}^{-1} \mathrm{~d}^{-1}$ when the amphipods were exposed to only ca $4 \mu \mathrm{g} \mathrm{Cd}^{2+} \mathrm{l}^{-1}$ in a total exposure of $50 \mu \mathrm{g} \mathrm{Cd} \mathrm{l^{-1 }}$ at $20 \% \mathrm{NaCl}$ (Fig. 2,

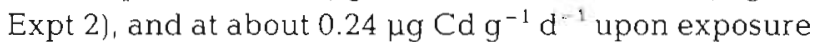
to $\mathrm{ca} 5.5 \mu \mathrm{g} \mathrm{Cd}^{2+} \mathrm{l}^{-1}$ in $100 \mu \mathrm{g} \mathrm{Cd} \mathrm{l^{-1 }}$ at $25 \% \mathrm{NaCl}$ (Fig. 3, Expt 3). Thus the amphipods are clearly capable of taking up cadmium at a greater rate than the apparently saturated rates indicated in Figs. $2 \& 3$.

Thus the availability of free $\mathrm{Cd}^{2+}$ ion has not saturated the system for taking up cadmium. It does remain possible that the cadmium is following the enzymedriven route of another (major?) metal ion $M$ (e.g. cal- cium), and that the rate of uptake of this metal has reached a maximum at a salinity between 20 and $15 \%$. Thus within an experiment the constant (maximum) uptake rate of $M$ would prevent further increase in the $\mathrm{Cd}$ uptake rate, although higher $\mathrm{Cd}$ uptake rates are possible at any given salinity if the $\mathrm{Cd}^{2+}: \mathrm{M}$ ratio is changed. However, even if the uptake rate of $M$ reached a maximum within a particular experiment, the $\mathrm{Cd}$ uptake rate should still increase on further reduction of salinity. It is the $\mathrm{Cd}^{2+}$ ion that is of similar ionic radius to $\mathrm{Ca}^{2+}$ and, even at a constant $\mathrm{Ca}^{2+}$ uptake rate, physico-chemical speciation changes would alter the $\mathrm{Cd}^{2+}: \mathrm{Ca}^{2+}$ ratio providing for an increased $\mathrm{Cd}$ a) $33 \mathrm{PPT} \mathrm{NaCl}$

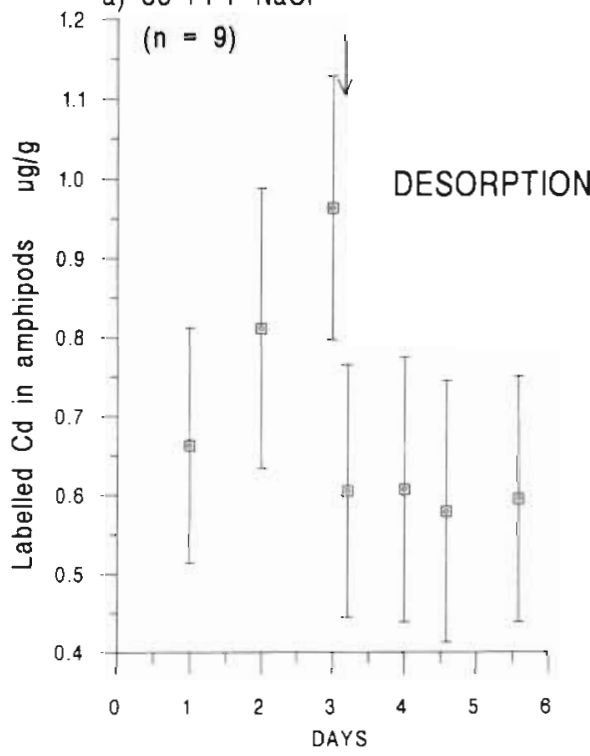

c) $15 \mathrm{PPT} \mathrm{NaCl}$

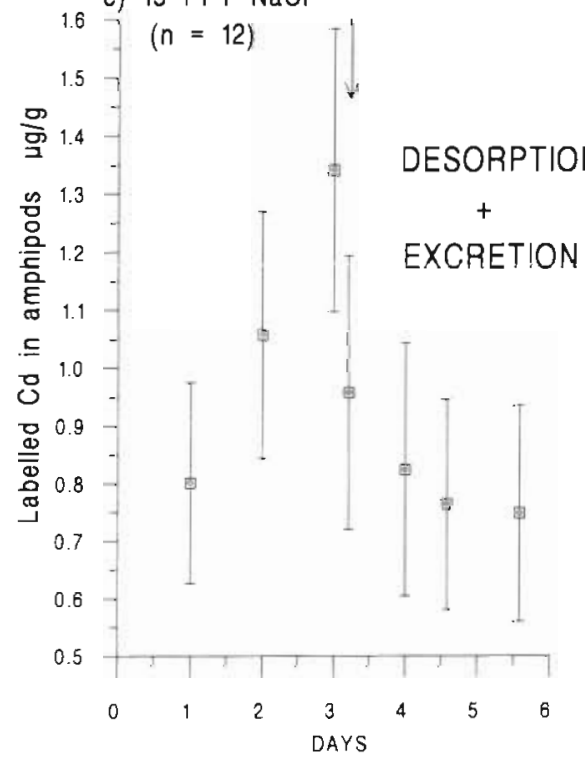

b) 27.5 PPT $\mathrm{NaCl}$

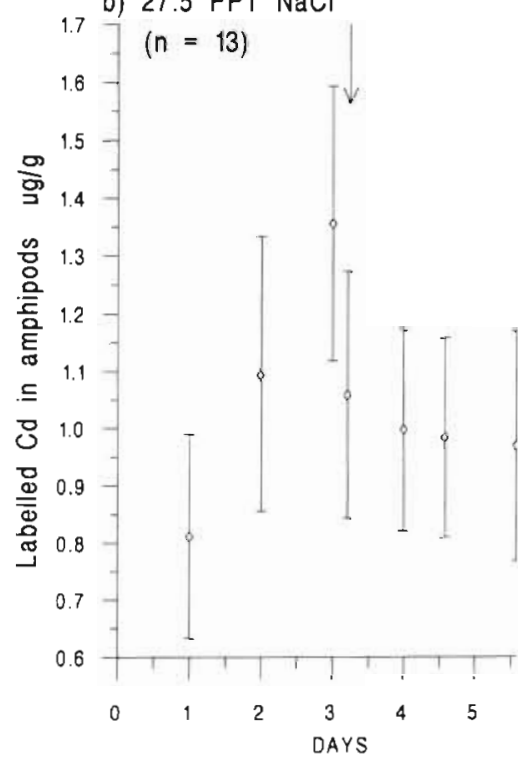

d) 6 PPT $\mathrm{NaCl}$

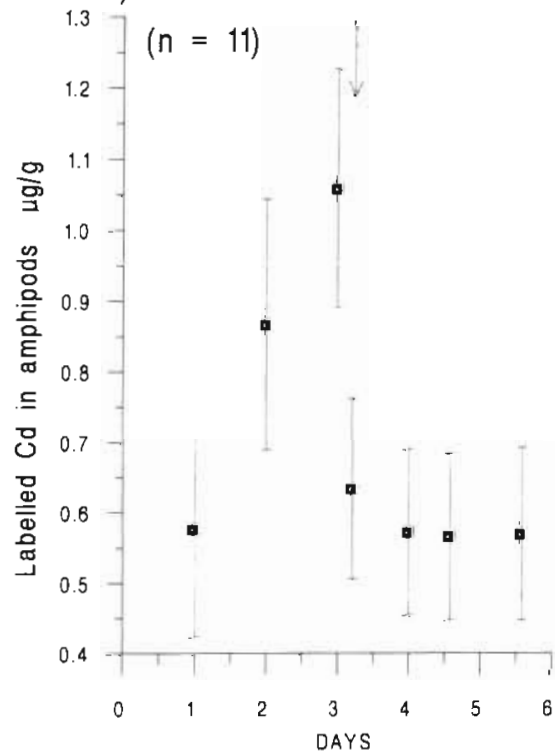

Fig. 8. Orchestia gammarellus. The patterns of accumulation of labelled $\mathrm{Cd}$ by amphipods (mean labelled $\mathrm{Cd} \pm 1 \mathrm{SD}$ ) exposed for $3 \mathrm{~d}$ to $100 \mathrm{Hg} \mathrm{l}^{-1}$ labelled $\mathrm{Cd}$ at $10^{\circ} \mathrm{C}$ at (a) 33, (b) 27.5 , (c) 15 and (d) $6 \% \mathrm{NaCl}$, followed by $3 \mathrm{~d}$ in medra of the same salunity without labelled $\mathrm{Cd}$ 
Fig. 9. Orchestia gammarellus. The patterns of accumulation of labelled $\mathrm{Zn}$ by amphipods (mean labelled $\mathrm{Zn} \pm 1 \mathrm{SD}$ ) exposed for $3 \mathrm{~d}$ to $100 \mathrm{\mu g} \mathrm{I}^{-1}$ labelled $\mathrm{Zn}$ at $10^{\circ} \mathrm{C}$ at (a) 33 , (b) 27.5 , (c) 15 and (d) $6 \% \mathrm{NaCl}$, followed by $3 \mathrm{~d}$ in media of the same salinity without labelled $\mathrm{Zn}$ a) 33 PPT $\mathrm{NaCl}$

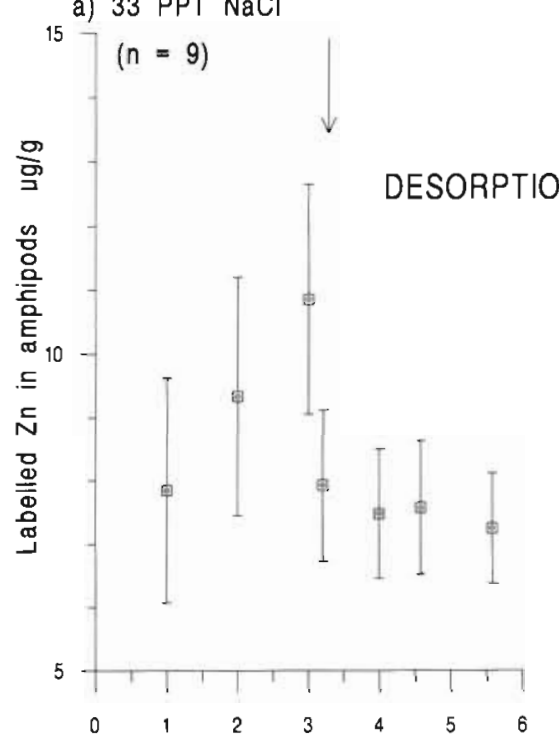

c) 15 PPT $\mathrm{NaCl}$

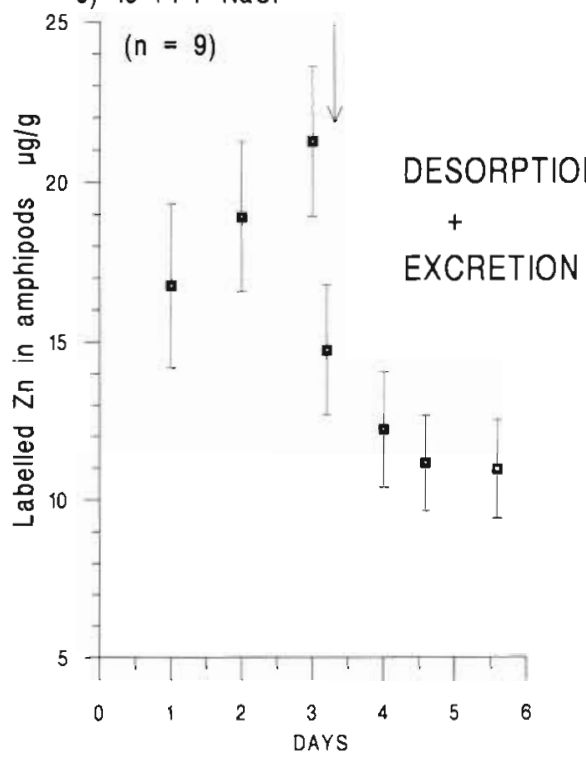

b) $27.5 \mathrm{PPT} \mathrm{NaCl}$

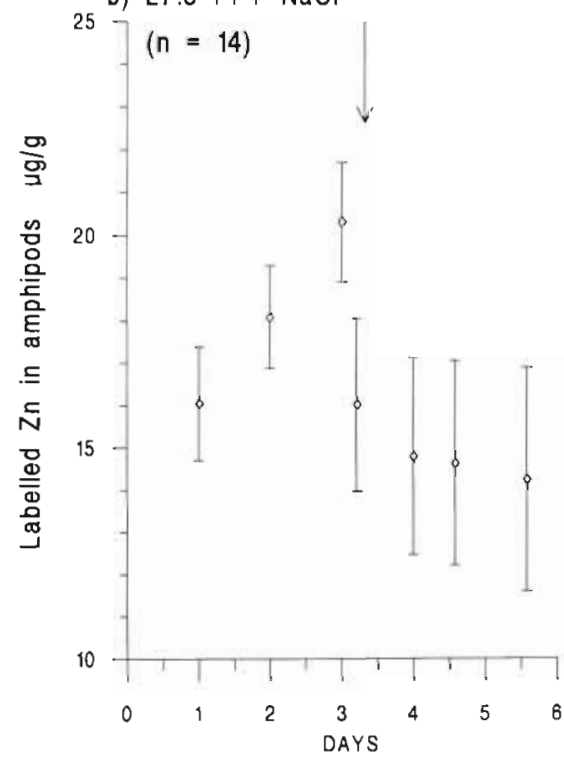

d) 6 PPT $\mathrm{NaCl}$

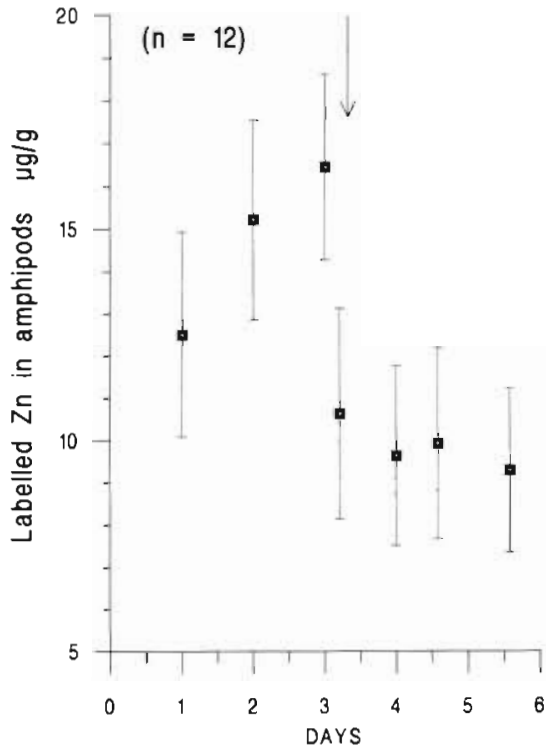

uptake rate at a fixed $\mathrm{Ca}^{2+}$ uptake rate. Thus the $\mathrm{Cd}$ uptake rate should not level out. Furthermore, given the differential effect of low salinity on cadmium and zinc speciation in $\mathrm{NaCl}$ (Rainbow et al. 1993), cadmium and zinc uptake rates would both increase with reduced salinities but at different rates if both were following the now maximized rate of uptake of $M$. Simply, $\mathrm{Cd}^{2+}: \mathrm{M}$ and $\mathrm{Zn}^{2+}: \mathrm{M}$ change differently as salinity is reduced. Neither the pattern of change of uptake rate of cadmium with low salinity (Rainbow et al. 1993, this study) nor that of zinc (Rainbow et al. 1993) follows that expected from the argument above, nor are the patterns for the 2 metals different from each other
A second point to note is the decrease in Cd uptake rate at $12 \%$ (Fig. 2). This observation is inconsistent with a saturable enzyme mechanism which demands a constant, or probably increasing, rate of Cd uptake at low salinities. It could be argued that the toxic metal cadmium may under these circumstances be having a direct toxic effect on the relevant enzyme itself (see Viarengo et al. 1994) and has caused a loss of enzyme activity during the uptake of $\mathrm{M}$ and incidentally cadmium. This argument again is not convincing given that no decrease in postulated enzyme activity is apparent in Fig. 6 of Rainbow et al. (1993) when amphipods were exposed to $500 \mathrm{\mu g} \mathrm{l}^{-1}$ total cadmium 
at 25 and $15 \%$. The cadmium uptake rate (ca $6 \mu \mathrm{g} \mathrm{Cd}$ $\left.\mathrm{g}^{-1} \mathrm{~d}^{-1}\right)$ is far higher than those reached here in either Fig. 2 (ca $0.14 \mu \mathrm{g} \mathrm{Cd} \mathrm{g}{ }^{-1} \mathrm{~d}^{-1}$ ) or Fig. 3 (ca $0.24 \mu \mathrm{g} \mathrm{Cd} \mathrm{g}{ }^{-1}$ $\mathrm{d}^{-1}$ ) without any apparent toxic effect dependent on $\mathrm{Cd}^{2+}$ concentration.

It is concluded therefore that the graphs presented for the effect of salinity change on Cd uptake rate do not themselves provide convincing evidence for an uptake mechanism driven by an enzyme with saturable kinetics. The same conclusion is reached here as was reached by Rainbow et al. (1993): at low salinities (below $25 \%$ but variably between amphipods) there is a physiological response on the part of the amphipod counteracting increases in the uptake rate of cadmium (and by extension zinc) promated by physico-chemical changes in free metal ion concentration caused by reduced inorganic complexation.

Expt 3 also investigated the effect of acclimation to low salinity $(15 \% \mathrm{NaCl})$ on such a physiological response. Since the experiments depicted in Figs. $2 \& 3$ were carried out over $4 \mathrm{~d}$ the physiological response at low salinity must be at least initiated within this period. A period of $7 \mathrm{~d}$ acclimation to $15 \% \mathrm{NaCl}$ was therefore chosen to at least initiate and by intention complete any physiological response. If for example the physiological response were to be in the form of a long-term change in AWP, then this should be reflected in differences between cadmium uptake rates of acclimated and non-acclimated amphipods at different salinities. As shown in Fig. 4 there appears to be no such longterm physiological change persisting on transfer back from low salinity to high salinity. Similarily Rainbow et al. (1993) found that $72 \mathrm{~h}$ acclimation of Orchestia gammarellus to $50 \%$ seawater $(16.5 \% \mathrm{NaCl})$ did not affect the subsequent uptake rate of cadmium or zinc from either $1.00 \%$ or $50 \%$ seawater.

Expt 4, measuring the uptake rate of zinc at different osmolities and salinities, confirms that the physiological response is a response to low osmolality independently of physico-chemical changes resulting from changes to salinity (inorganic ion concentrations).

The use of the 3-treatment protocol (Expt 5) allowed further separation of the effects of salinity and osmolality on trace metal uptake rates. In the case of cadmium (Table 2), the addition of fructose to a medium of $15 \%$ salinity confirmed that the increased rate of Cd uptake at low salinity can be explained by physico-chemical changes, as opposed to changes in calcium pump activity being the cause of changes in cadmium uptake rate. The latter would respond to osmolality changes and no such response was observed; in the final comparison in Table 2, there was no difference in osmolality across the 3 treatments, but there was a clear difference in cadmium uptake rates, unexpected from calcium pump incorporation yet explicable by differ- ences in free cadmium ion availability to a facilitated diffusion transfer system.

The results for zinc (Table 3 ) are less convincing In this experiment there were unexpectedly no significant differences between zinc uptake rates at 15 and $33 \% \mathrm{NaCl}$ (compare Table 1). The effect of reduced salinity on the complexation of zinc is admittedly much less than that on the complexation of cadmium (Rainbow et al, 1993) leading to a smaller physico-chemical effect at low salinity, but the inconsistency between experiments is frustrating. The significant difference between zinc uptake rates in the final comparison of Table 3 is nevertheless consistent with that seen for cadmium (Table 2).

As expected the uptake rate of calcium by Orchestia gammarellus increases with decreased salinity. Interestingly the calcium uptake rate appears to level off between $15 \%$ and $20 \% \mathrm{NaCl}$, as do cadmium and zinc uptake rates. The rate of calcium uptake may be responding to the same physiological effect. Alternatively it could be argued that the zinc and cadmium uptake rates directly follow the calcium uptake rate. Given the discussion above concerning cadmium uptake following the enzyme-driven uptake of another metal such as calcium, it is hard to be convinced b; his argument, particularly since the calcium uptake ate rises again at $6 \% \mathrm{NaCl}$. In contrast, the cadmium. iptake rate falls again at $12 \% \mathrm{NaCl}$ (Fig. 2) and it is c ficult to ascribe this to a toxic effect of cadmium (see awove).

A change in AWP upon exposure to low salinity was a strong candidate to explain the physiological response seen in the effect of reduced salinity on cadmium and zinc uptake rates (see also Chan et al. 1992. Rainbow et al. 1993). The results shown in Table 4, however, rule against changes in AWP being the explanation in Orchestia gammarellus, although they may play a role when salinities fall as low as $6 \%$.

The final experiment casts some light on another aspect of the physiology of trace metal accumulation in Orchestia gammarellus. It does appear that at $15 \%$ $\mathrm{NaCl}$ but not at 33 or $27.5 \% \mathrm{NaCl}$, the amphipods might be excreting accumulated cadmium and zinc. The extent of such excretion, however, is not sufficient to explain all of the drop from the expected cadmium uptake rate when the amphipods are exposed to $100 \mu \mathrm{g}$ $\mathrm{Cd}^{-1}$ at $15 \% \mathrm{NaCl}$ (Fig 3). If the labelled cadmium uptake rate had continued to increase linearly in proportion to the free $\mathrm{Cd}$ ion concentration between 25 and $15 \% \mathrm{NaCl}$ (Fig. 3), the expected uptake rate would have been about $0.44 \mu \mathrm{g} \mathrm{Cd} \mathrm{g}^{-1} \mathrm{~d}^{-1}$ as opposed to about $0.28 \mu \mathrm{g} \mathrm{Cd} \mathrm{g}{ }^{-1} \mathrm{~d}^{-1}$ observed, a shortfall of about $0.17 \mu g \mathrm{Cd} \mathrm{g}^{-1} \mathrm{~d}^{-1}$. If Fig. 8c does show excretion, then the fall in accumulated labelled $\mathrm{Cd}$ between the fourth and sixth points is about $0.20 \mu \mathrm{gg}{ }^{1}$ in $2 \mathrm{~d}$. Such an excretion rate is less than the daily shortfall above. 
Other possible physiological responses are changes in absolute or relative rates of gill (pleopod) ventilation and blood perfusion through the gills, which may change with salinity. It is, however, unlikely that these will affect metal uptake (Depledge \& Rainbow 1990). Seawater passing over a respiratory surface will lose only a minute amount of its dissolved trace metal load during transit. Similarly the increase in the metal concentration of the blood during perfusion will also be minute. Thus any alteration in ventilation and perfusion rates is unlikely to affect the trace metal concentration gradient across the respiratory surface.

In conclusion therefore, several effects appear to interact to affect the uptake rates of zinc and cadmium by Orchestia gammarellus. Firstly there is a physicochemical effect on metal speciation at all salinities, with consequences for the incorporation of the free metal ion (promoted by low salinity) into both facilitated diffusion transport active pathways but also into any active pumps transporting major metal ions via changes in $\mathrm{Cd}^{2+}: \mathrm{M}$ or $\mathrm{Zn}^{2+}: \mathrm{M}$ ratios.

Secondly trace metal uptake rates may be affected by the rate of activity of active pumps for major ions such as calcium, changing with salinity but also with individual physiologies, not least stage of the moult cycle. Such major ion pumps would promote the uptake of trace metals at reduced salinity but do not themselves offer the only route for metal uptake. There is little evidence for this particular route being of significance in Orchestia gammarellus under the conditions examined here, but this significance may change under different physiological and ecological conditions.

Thirdly a physiological effect comes into action in Orchestia gammarellus at salinities below $20 \%$ reducing cadmium and zinc uptake. This physiological response is not simply a change in apparent water permeability for, in this amphipod, AWP changes are only significant at extremes of the salinity range. Nor can the physiological effect be completely explained by the inaccuracies of using net accumulation of metal as a measure of absolute uptake of metal at $15 \%$. Excretion of cadmium at $100 \mu \mathrm{g} \mathrm{Cd} \mathrm{^{-1 }}$ in a medium of $15 \%$ did not match the shortfall in the cadmium uptake rate expected from speciation effects.

The identification of the physiological effect therefore remains enigmatic, but it is possible that it will turn out to be the net effect of a combination of physiological responses.

Acknowledgements. This work was supported by NERC grant GR3/8294 to P.S.R. We are also grateful to Prof. Paul O'Brien for advice on speciation, to Brian Smith for his technical support, and to anonymous referees for constructive comments.

\section{LITERATURE CITED}

Bolt SRL (1983) Haemolymph concentration and apparent permeability in varying salinity conditions of Gammarus duebeni, Chaetogammarus marinus and Gammarus locusta. J exp Biol 107:129-140

Böttcher $K$, Siebers D (1993) Biochemistry, localisation and physiology of carbonic anhydrase in the gulls of euryhaline crabs. J exp Zool 265:397 409

Bruland KW (1983) Trace elements in seawater In: Riley JP, Chester R (eds) Chemical oceanography, Vol 8. Academic Press, London, p 157-220

Bryan GW (1966) The metabolism of $\mathrm{Zn}$ and ${ }^{65} \mathrm{Zn}$ in crabs, lobsters and fresh-water crayfish. In: Aberg B, Hungate FP (eds) Radioecological concentration processes. Pergamon Press, Oxford, p 1005-1016

Bryan GW (1968) Concentrations of zinc and copper in the tissues of decapod crustaceans. J mar biol Ass UK 48:303-321

Campbell PJ, Jones MB (1990) Water permeability of Palaemon longirostris and other euryhaline caridean prawns. $J$ $\exp$ Biol 150:145-158

Chan HM, Bjerregaard P, Rainbow PS, Depledge MH (1992) Uptake of zinc and cadmium by two populations of shore crabs Carcinus maenas at different salinities. Mar Ecol Prog Ser 86:91-97

Depledge MH, Rainbow PS (1990) Models of regulation and accumulation of trace metals in marine invertebrates. Comp Biochem Physiol 97C:1-7

Huheey JE (1983) Inorganic chemistry, 3rd edn. Harper International, Cambridge

Hutcheson MS (1974) The effect of temperature and salinity on cadmium uptake by the blue crab Callinectes sapidus. Chesapeake Sci 15:237-241

Lockwood APM, Inman CBE (1973) Water uptake and loss in relation to the salinity of the medium in the amphipod crustacean Gammarus duebeni. J exp Biol 58:149-163

Mantel LH. Farmer LL (1983) Osmotic and ionic regulation In: Mantel LH (ed) The biology of Crustacea, Vol. 5. Academic Press, New York, p 53-161

Mantoura RFC, Dickson A, Riley JP (1978) The complexation of metals with humic materials in natural waters. Estuar coast mar Sci 6:387-408

Nieboer E, Richardson DHS (1980) The replacement of the nondescript term 'heavy metals' by a biologically and chemically significant classification of metal ions. Environ Pollut 1:3-26

Nugegoda D, Rainbow PS (1988) Effect of a chelating agent (EDTA) on zinc uptake and regulation by Palaemon elegans (Crustacea: Decapoda). J mar biol Ass UK 68: $25-40$

Nugegoda D, Rainbow PS (1989a) Effects of salinity changes on zinc uptake and regulation by the decapod crustareans Palaemon elegans and Palaemonetes varians. Mar Ecol Prog Ser 51:57-75

Nugegoda D, Rainbow PS (1989b) Salinity, osmolality, and zinc uptake in Palaemon elegans (Crustacea: Decapoda). Mar Ecol Prog Ser 55:149-157

O'Brien P, Rainbow PS, Nugegoda D (1990) The effect of a chelating agent EDTA on the rate of uptake of zinc by Palaemon elegans (Crustacea: Decapoda). Mar environ Res 30:155-159

O'Hara J (1973a) The influence of temperature and salinity on the toxicity of cadmium to the fiddler crab, Uca pugilator. Fish Bull US 7 1:149-153

O'Hara J (1973b) Cadmium uptake by fiddler crabs exposed to temperature and salinity stress. J Fish Res Bd Can 30 . $846-848$ 
Rainbow PS (1987) Heavy metals in barnacles. In: Southward AJ (ed) Barnacle biology. AA Balkema, Rotterdam, $p$ $405-417$

Rainbow PS (1988) The signuficance of trace metal concentrations in decapods. Symp zool Soc London 59:291-313

Rainbow PS (1993) The significance of trace metal concentrations in marine invertebrates. In: Dallinger R, Rainbow PS (eds) Ecotoxicology of metals in invertebrates. Lewis Publishers, Boca Raton, p 3-23

Rainbow PS (1995) Physiology, physicochemistry and metal uptake - a crustacean perspective. Mar Pollut Bull 31: 55-59

Rainbow PS, Dallinger R (1993) Metal uptake, regulation and excretion in freshwater invertebrates. In: Dallinger $R$, Rainbow PS (eds) Ecotoxicology of metals in invertebrates Lewis Publishers, Boca Raton, p 119-131

Rainbow PS, Malik I, O'Brien P (1993) Physicochemical and physiological effects on the uptake of dissolved zinc and cadmium by the amphipod crustacean Orchestia gammarellus. Aquat Toxicol 25:15-30

Simkiss K, Taylor MJ (1989) Metal fluxes across the membranes of aquatic organisms. CRC crit Rev aquat Sci 1. $178-188$

Smith RI (1970) The apparent water-permeability of Carcinus maenas (Crustacea, Brachyura, Portunidae) as a function of salinity. Biol Bull 139:351-362

Towle DW (1993) Ion transport systems in membrane vesicles

This article was submitted to the editor isolated from crustacean tissues. J exp Zool 265:387-396 Turner DR, Whitfield M, Dickson AG (1981) The equilibrium speciation of dissolved components in freshwater and seawater at $25^{\circ} \mathrm{C}$ and $1 \mathrm{~atm}$ pressure. Geochim Cosmochim Acta 45:855-881

Viarengo A, Canesi L, Moore MN, Orunesu M (1994) Effects of $\mathrm{Hg}^{2+}$ and $\mathrm{Cu}^{2+}$ on the cytosolic $\mathrm{Ca}^{2+}$ level in molluscan blood cells evaluated by confocal microscopy and spectrofluorimetry. Mar Biol 119:557-564

Weeks JM, Rainbow PS (1991) The uptake and accumulation of zinc and copper from solution by two species of talitrid amphipods (Crustacea). J mar biol Ass UK 71:811-826

White SL, Rainbow PS (1984) Regulation of zinc concentration by Palaemon elegans (Crustacea: Decapoda): zinc flux and effects of temperature, zinc concentration and moulting. Mar Ecol Prog Ser 16:135-147

Wright DA (1977a) The effect of salinity on cadmium uptake by the tissues of the shore crab Carcinus maenas. $J$ exp Biol 67:137-146

Wright DA (1977b) The effect of calcium on cadmium uptake by the shore crab Carcinus maenas. J exp Biol 67:163-173

Wright DA (1980) Cadmium and calcium interactions in the freshwater amphipod Gammarus pulex. Freshwat Biol 10: $123-133$

Zirino A, Yamamoto S (1972) A pH-dependent model for the chemical speciation of copper, zinc, cadmium, and lead in seawater. Limnol Oceanogr 17:661-671

Manuscript first received: December 22, 1994

Revised version accepted: May 12, 1995 